\title{
Kadına Yönelik Şiddet: Sebepleri, Önlemeye Yönelik Kur'anî Tedbirler
}

\author{
Dr. Öğr. Üyesi Mehmet KILIÇARSLAN ${ }^{*}$
}

Atıf / @-- Kılıçarslan, M. (2018). Kadına Yönelik Şiddet: Sebepleri, Önlemeye Yönelik Kur'anî Tedbirler, Çukurova Üniversitesi İlahiyat Fakültesi Dergisi, 18 (2), 958-994.

Öz-Kadına yönelik şiddet, dünyanın tedavi edilemez bir yarası haline gelmiştir. Resmi, gayr-ı resmi ve karma olmak üzere pek çok çalışma yapılmasına; bu ilkelliğin önüne geçmek için sürekli yeni kanunlar çıkarılmasına; seminer, panel, sempozyum, konferans gibi halka açık, kurum içi personel eğitimleri gibi lokal çalışmalar yapılmasına rağmen gün geçtikçe artmaya devam etmektedir. Kadına yönelik şiddet, kadının erkek karşısındaki güçsüzlüğü, kadının cinsiyeti/cinselliği, reddedilme, ekonomik nedenler, kültürel nedenler, kanunların yetersizliği, beşeri nedenler ve eğitim eksikliği başta olmak üzere pek çok sebebi olan bir olgudur ve bütün dünyanın kendisiyle mücadele ettiği ortak bir sorundur. Ancak İslam karşıtı bazı çevreler, sanki sadece Müslüman ülkelerde kadına şiddet uygulanıyormuş ve bunun yegâne müsebbibi İslam diniymiş gibi bir algı oluşturmaya, insan hakları ve kadın hakları üzerinden Islam'a saldırmaya devam etmektedir. Bu dinin iki kaynağı, Kur'an-ı Kerim ve Sünnet-i Seniyye, incelendiğinde bugün İslam'a saldıranların atalarının kadının bir insan olup olmadığını tartıştıkları dönemlerde, kadına birçok hak ve yetkiyi verdiği görülecektir. Bu çalışmada kadına yönelik şiddetin nedenleri başlıklar halinde belirlenecek, daha sonra bunları engellemeye yönelik Kur'anî tedbirler verilecektir. Kadına şiddetin nedenlerini topluca bir arada görmesi sağlanan okuyucunun, bunun İslam'la bir ilgisinin olmadığını fark etmesi; Kur'an'ın kadını korumaya yönelik tedbirlerini bir arada görmesiyle de onun bir sorun kaynağı değil, çözüm merkezi olduğunu müşahede etmesi hedeflenmektedir.

Anahtar sözcükler-Kadın, şiddet, neden, Kur'an, tedbir

\section{$\S \S \S$}

\section{Giriş}

Haksız yere güç ve kuvvet uygulama, kişinin vücuduna ya da saygınlığına yönelik ihlalde bulunma ve hakkaniyeti yansıtmayacak şekilde

\footnotetext{
* Nevşehir Hacı Bektaş Üniversitesi İlahiyat Fakültesi Tefsir Anabilim Dalı. e-posta: 76mkaa@gmail.com, ORCID: 0000-0001-6935-1878
} 
karşı tarafı olumsuzlama ${ }^{1}$ şekillerinden biriyle önümüze çıkan şiddet, insanlık tarihi kadar eski bir olgudur. Âdem'in oğlu Kâbil'in kardeşi Hâbil'e uyguladığı şiddet, bütün ilahî kaynaklarda kendisine yer verilen, insanlık tarihinin bilinen ilk şiddet örneğidir. ${ }^{2}$ Gayr-ı meşru olan, asla haklı gösterilemeyecek, onaylanması mümkün olmayan her türlü güç uygulaması şiddet olduğu gibi; kişinin rızası olmadan onun bedenine ya da saygınlığına yönelik yapılan her türlü müdahale, saldırı ve temas da şiddettir. Bir de olumsuzlama şeklinde tezahür eden şiddet vardır ki, bu şiddet türünde karşıdakini ötekileştirme, onun haklarını yok sayma, fiziksel ya da psikolojik güç kullanarak muhatabın saygınlığını ortadan kaldırmaya çalışma söz konusudur. ${ }^{3}$ Her insan, salt insan olmakla, sayılan şiddet türlerinin tamamından korunma hakkına sahiptir. Eğer kendisini koruyamıyorsa, bu korumayı ona, içinde yaşadığı toplum sağlamak zorundadır. Zira bu, insan haklarının en öncelikli ve en vazgeçilmez bölümünü oluşturmaktadır. Hiç kimseden, bu hakkından feragat etmesi beklenemez.

Genel anlamda insan hakları özelde de kadın hakları kavramı, Birleşmiş Milletlerin 'Kadınlara Karşı Her Türlü Ayrımcılığın Önlenmesi Sözleşmesi (CEDAW)'ı 1980'de üye ülkelerin imzasına açmasıyla ülkemiz gündemine de girmiş; o günden beri, sürekli artan bir ilgiyle gündemde kalmayı sürdürmüştür. 1926 yılında Medeni Kanun'un kabulüyle birlikte çok eşliliğin kaldırılması ve kız çocuklarının mirasta erkekle eşit olduğunun hükme bağlanması da kadına tanınmış haklar olarak nitelenebilir. Ancak çıkarılan kanunlar uygulamaya yansımadığı ve pratik hayatta istenen karşılığı bulmadığı için çok ses getirmemiştir. ${ }^{4}$

Kadına yönelik şiddet ise, tarih boyunca ailenin bir iç meselesi gibi algılanmış, sadece eşleri ilgilendirdiği ön kabulüyle ne resmi ne örfi anlamda bunun engellenmesi için hiçbir adım atılmamıştır. 2000'li yılların başından itibaren Avrupa Birliği üyeliği için gerekli olan hukuki alt yapıyı oluşturma zorunluluğuyla birlikte resmi adımlar atımaya, anayasal ve yasal değişiklikler

\footnotetext{
1 Şiddetin tanımı, türleri ve kapsamı hakkında geniş bilgi için bkz. Celal Türer, Şiddet Karşısında İslam, (İstanbul: DỉB Yayınları, 2014), 13-26.

2 Tevrat'ta Kâbil, 'Kayin' ismiyle geçer. Kâbil ve Hâbil her ikisi de Allah'a bir adak sunar. Hâbil'inki, malının en iyi kısmından verdiği için Allah tarafından kabul edildiği halde Kâbil'inki kabul edilmez. Bunu kabullenemeyen Kâbil, kıskançlıkla kardeşini öldürür. (Yaratıış, 4/8). Aynı bilgi, Kur'an-ı Kerim'de de isimler zikredilmeden geçer. Kur'an'da da Allah'a adak sunan iki kardeşten birinin, malının en iyilerini Allah'a sunması nedeniyle kurbanının kabul edildiği, ikincisinin ise malının kötü olanından verdiği için kabul edilmediğine vurgu yapılır ve öldürmenin kıskançlık kaynaklı olduğuna değinilir. (el-Mâide, 5/27-30).

3 Türer, Şiddet Karşısında İslam, 15-19.

${ }^{4}$ Şafak Kaypak ve Mehmet Kahraman, "Türkiye'de Kadının İnsan Hakları Ve Anayasal Yansıması," Mustafa Kemal Üniversitesi Sosyal Bilimler Enstitüsü Dergisi 13/XXXIII (2016): 298-315.
} 
yapılmaya; yasaların uygulanabilirliğini sağlamak için de kanun hükmünde kararnameler, tüzükler, yönetmelikler, yönergeler ve genelgeler çıkarılmaya başlanmıştır. ${ }^{5}$

Kur'an-ı Kerim, kadını ve kadının mali haklarını korumak maksadıyla bundan 1400 sene önce bir takım hükümler koymuştur. İnsan yerine bile konulmayan, bir mal gibi alınıp satılan, katiline hiçbir ceza uygulanmayan, günahsız bir bebekken diri diri toprağa gömülerek öldürülen kadına çok özel bir statü tanımış, onu her yönüyle erkeğe eş kabul etmiştir. ${ }^{6} \mathrm{~K} ı \mathrm{z}$ çocuklarının öldürülmesi geleneğini tamamen ortadan kaldırmış, kadın-erkek ayrımı yapmadan cinayet işleyene kısas uygulanacağını bildirerek canını emniyet altına almış, mirastan ödenmesi zorunlu bir pay belirlemiş, evlilik esnasında kendisine mehir ödenmesini ve kendi şartlarını ileri sürmesini hükme bağlamıştır. Hatta bir nikâh akdi yapıldığı halde düğün gerçekleşmemişse, böylesi bir nikâhın sonlandırılması durumunda bile belirlenen mehrin yarısını ödemeyi erkeğe emretmiştir. ${ }^{7}$ Evlilik süresince kadının her türlü ihtiyacını karşılama sorumluluğunu erkeğe yüklediği gibi, evliliğin son bulması halinde kadının mağdur olmasını engelleyecek muvakkat nafakalar da belirlemiştir. ${ }^{8}$ Evlenme ve boşanmayı belli kurallara bağlaması da kadın için büyük bir devrim olmuş, onu erkeğin elinde bir oyuncak olmaktan kurtarmış; hem imgesel olarak hem de gerçek anlamda kadınla erkeği aynı konuma oturtmuştur.

Kur'an'ın şiddeti engellemeye yönelik tedbirlerini ele almadan önce, kadına şiddet uygulamanın temel nedenlerini doğru belirlemek gerekir. Bu amaçla çalışmamızı iki bölüme ayıracağız. İlk bölümde, kadına uygulanan şiddetin temel nedenlerini ortaya koymaya; ikinci bölümde, Kur'an'ın bu meyanda aldığı tedbirleri belirlemeye gayret edeceğiz.

\section{A. Kadına Yönelik Şiddetin Nedenleri}

Kadına uygulanan şiddetin pek çok türü vardır. Cinsel şiddet, psikolojik şiddet, fiziksel şiddet, ekonomik şiddet, çeşitli nedenlerle mesleğini rahatça icra etmesini engellemeye yönelik şiddet (mobbing) vb. en fazla öne çıkan türlerdir. Bir de bu saydığımız türlerin tamamını kapsayan ve aile içi şiddet diye adlandırılan bir tür vardır ki, bunun sınırlarını belirlemek bile çok zordur. 2005

\footnotetext{
${ }^{5}$ Necla Öztürk, "Ailenin Korunması Ve Kadına Karşı Şiddetin Önlenmesine Dair Kanunun Getirdiği Bazı Yenilikler ve Öneriler," Inönü Üniversitesi Hukuk Fakültesi Dergisi 8/I (2017): 1-32.

${ }^{6}$ Hayrettin Karaman vd., Kur'an Yolu, (Ankara: DỉB Yayınları, 2014), 1/265-270.

${ }^{7}$ el-Bakara, 2/237.

${ }^{8}$ el-Bakara, 2/233.
} 
yılında yapılan bir araştırmaya göre katılımcı kadınları \%40,7'si, aile içi şiddete maruz kalmakta; maalesef bu şiddeti uygulayan da \% 91,1 gibi bir oranda eşler olmaktadır. ${ }^{9}$ Aile ve Sosyal Politikalar Bakanlığı Kadının Statüsü Genel Müdürlüğü'nce alanında uzman bir ekibe hazırlatılan "Türkiye'de Kadına Yönelik Şiddetle Mücadele" broşüründe verilen bir bilgiye göre, 2014 yılında gerçekleştirilen “Türkiye'de Kadına Yönelik Aile İçi Şiddet Araştırması"nın sonuçları şöyledir: Kadınların yüzde 36'sı yaşamının herhangi bir döneminde eşi veya birlikte olduğu erkeklerin fiziksel şiddetine, \%12'si cinsel şiddete, \%44'ü psikolojik şiddete, \%30'u ekonomik şiddete maruz kalmaktadır. ${ }^{10}$

Burada asıl önemli konu, böylesine geniş bir yelpazede kadına karşı şiddet uygulanmasının nedenleridir. Bu nedenleri şu başlıklar altında ele almak mümkündür:

1. Kadının Erkek Karşısındaki Güçsüzlüğü: Kadının güçsüzlüğünü iki başlık halinde ele almak gerekir. İş yapabilirlik anlamında güçsüzlük: Öncelikle belirtmek gerekir ki bu, gerçek anlamda bir güçsüzlük değildir. Kadınların da hemen her işi erkeklerle aynı kalitede yapabildiği apaçık ortadadır. Bu güçsüzlük, erkek egemen toplumlar tarafından oluşturulan sosyo-politik, ekonomik ve kültürel ortam nedeniyle kadının, sahip olduğu melekeleri, yetenek ve becerileri ortaya koymasının engellenmesinden kaynaklı bir güçsüzlüktür. Ancak bu, öylesine uzun vadeli olarak zihinlere işlenmiş bir imgelemdir ki hem kadın hem de erkek bunu peşinen kabullenmiş ve yadsımaz hale gelmiştir. ${ }^{11}$ Aslında pekâlâ yapabileceği bir iş kadına teklif edildiğinde, hiç düşünmeden ' $O$, erkek işi. Ben yapamam' diyebilmektedir. Bunun arkasında, 'Ben bu işe girersem el âlem ne der' ya da 'Adımı kötüye çıkarırlar' vb. kaygılar yatmakta; öğrenilmiş bir çaresizlik, dışa vurulmaktadır. ${ }^{12}$ Fiziksel güçsüzlük: Bu, yaratılıştan gelen fıtri bir güçsüzlüktür. Kendisine kadını koruması ve ona yapılacak harici saldırıları engellemesi için güç verilen erkek, maalesef gücünü kadına karşı kullanabilmektedir. Türkiye'de toplam 56 ilde 1800 kadına yönelik yapılan bir çalışmada, her üç kadından birine kocası tarafından fiziksel şiddet

\footnotetext{
${ }^{9}$ Nuran Güler, Hatice Tel, ve Fatma Özkan Tuncay, "Kadının Aile İçi Şiddete Bakışı," CÜ Tıp Fakültesi Dergisi 27/II (2005): 51-56.

${ }^{10} \mathrm{http} / / /$ kadininstatusu.aile.gov.tr/data/58528516369dc524d057a5fe/Kad\%C4\%B1na\%20Yo\%CC \%88nelik\%20\%C5\%9Eiddetle\%20Mu\%CC\%88cadele\%20Bro\%C5\%9F\%C3\%BCr\%C3\%BC.pdf (erişim 01 Mayıs, 2018)

11 Kadındaki kültürel rolünü kabullenmişlikle ilgili detaylar için bkz. Selam Dinç Kahraman, "Kadınların Toplumsal Cinsiyet Eşitsizliğine Yönelik Görüşlerinin Belirlenmesi," DEUHYO ED 3/I (2010): 30-35.

${ }^{12}$ Erkeğin şiddete başvurma nedenlerini toplu bir arada görmek için bkz. Sevim Atila Demir, Dilek Nam, "Kadına Yönelik Aile İçi Şiddeti Önlemede Erkeğin Rolü," Süleyman Demirel Üniversitesi Íktisadi ve İdari Bilimler Fakültesi Dergisi 19/III (2014): 211-227.
} 
uygulandığı tespit edilmiştir. ${ }^{13}$ Böylesi bir kullanımın altında, kadına şiddet uygulamanın normal kabul edildiği bir ortamda büyüme, erkeğin de zamanında şiddete maruz kalması ve bunu kanıksaması; toplumda kendini ispatlayamama, harici faktörler karşısında yaşadığı ezilmişliklerde kadına güç uygulayarak kendini güçlü hissetme ve tatmin olma isteği, küçükken kadına şiddet uygulandığına tanıklık etme gibi çeşitli etkenler yatmaktadır.

2. Kadının Cinsiyeti/Cinselliği: Kadının cinsiyetini bahane ederek cinselliğini kontrol etme isteği de kadına uygulanan şiddetin bir başka nedenidir. Türkiye gibi büyük çoğunluğu Müslümanlardan oluşan bir ülkede dahi cinsellik, din dışı oluşan geleneğe bağlı olarak sadece erkeğe özgü bir hak gibi telakki edilmekte; erkeğin bu anlamdaki hataları çeşitli kılıflarla kamufle edilmektedir. Erkeğin nikâh dışı ilişkileri, çapkınlık, kaçamak ve aşk yaşama gibi basit kelimelerle geçiştirilerek, 'Erkektir, yapar' mantığıyla görmezden gelinirken; kadının benzer bir hata yapması, çok rahatlıkla kendisinin ölüm fermanı olabilmektedir. Ancak bu cümle, erkeğe verilen bu özgürlük ve gösterilen hoşgörü kadına da gösterilsin; kadın da cinsel tercihlerini dilediği gibi yaşasın anlamında söylenmiş değildir. Sadece olguyu resmetmek adına kurulmuştur. Nesillerin koruma altına alındığı ve neseplerin karışmasına izin vermeyen, çeşitli cinsel hastalıkların toplumda yayılmasını engelleyen, toplumun fertleri arasında güvene dayalı sağlıklı ilişkilerin kurulmasını sağlayan, doğacak çocuğa, babasının soyadını alma ve mirasından yararlanma gibi hak ve imkânlar tanıyarak onu koruma altına alan, kadını cinsel bir meta gibi görülmekten kurtarıp 'annelik' ve 'eş' gibi yüce sıfatlarla anılmasını sağlayan nikâha dayalı birliktelikler, hem dinin hem de fıtratın bir gereğidir. Ancak erkek, her türlü gayr-ı ahlaki ve gayr-ı meşru ilişkiyi kendisi için bir hak olarak görürken; kadını, hiç tanımadığı biri kendisine baktı diye rahatıkla hesaba çekebilmekte, hatta darp edebilmektedir.

3. Reddedilme: Kadın tarafından reddedilen erkeğin şiddete başvurduğu, inkâr edilemez bir olgudur. Bu reddedilme ile iki şeyi kastediyoruz: Dışarıdan ve içeriden reddedilme. Dışarıdan reddedilme ile kastımız; evli, nişanlı, sözlü ya da sevgili olma gibi kadınla hiçbir ilgisi ve bağı olmayan bir erkeğin, kadına gelip bu ilişkilerden birini kurma teklifi yaptığında, olumlu cevap alamadığı durumlardır. Kadın onun bu isteğini kabul etmeye mecburmuş gibi hisseden, kadını sevdiği için kabul edilmeyi kendi hakkı gibi telakki eden,

\footnotetext{
${ }^{13}$ Semra Erdoğan, Aylin Aktaş, ve Güliz Onat Bayram, "Sığınma Evinde Yaşayan Bir Grup Kadının Şiddet Deneyimleri Ve Baş Etme Yaklaşımları: Niteliksel Bir Çalışma," Uluslararası Insan Bilimleri Dergisi 6/l (2009): 808-824.
} 
reddedilmeyi hazmedemeyen psikolojisi bozuk bazı erkekler; kadının yüzüne asit/kezzap atma, ${ }^{14}$ yüzünü çeşitli sıcak sıvılarla yakarak bakılamaz hale getirme ve hatta zaman zaman öldürmeyle sonuçlanan ${ }^{15}$ çeşitli şiddet eylemlerine başvurabilmektedir. ${ }^{16}$

Bir de içeriden reddedilme vardır ki bununla kastımız, yukarıda sayılan evli, nişanlı, sözlü, sevgili olma gibi bir ilişkiyle, kadınla erkeğin bir bağının var olduğu durumlardır. Bu da kendi içerisinde iki şekilde tezahür etmektedir: Basit reddedilme, ciddi reddedilme. Erkeğin ailesiyle aynı evde yaşama talebinden tutun da cinsel birliktelik talebinin reddine varana kadar çeşitli reddedilme durumlarında kadın, erkeğin isteklerine hayır dediği için cinsel, psikolojik, fiziksel ve ekonomik şiddet türlerinden birine veya aynı anda birkaçına maruz kalabilmektedir. Çoğunlukla bunun altında başka etkenler yatar. Erkeğin karakterindeki zayıflık nedeniyle etrafındaki insanlardan etkilenmesi, ataerkil bir toplum yapısı olan ülkemizde ailesi ve arkadaş çevresi tarafından bu yönde erkeğe çeşitli telkinlerde bulunulması ya da manevi baskılar yapılması, erkekteki kendini yetersiz görme psikolojisi gibi çeşitli etkenler bu şiddetin alt yapısını oluşturmaktadır. Bir de ciddi reddedilme durumu vardır ki, en elim sonuçlar bu reddedilme türünde ortaya çıkmaktadır. Kadının erkekle olan bağını tamamen koparmak istemesi şeklinde tezahür eden bu türde; erkek, kendisini ihanete uğramış hissetmekte, şiddetin dozunu arttırabilmektedir. Boşanma davası açan eşini, hatta onunla beraber yanlarına sığındığı ailesinin

\footnotetext{
14 Örnek Olay: “Eskişehir'de M. L.'nin yüzüne I.C. isimli erkek tarafından kezzap atıldı. Yüzünde yanıklar oluşan kadın, saldırıdan 10 gün önce I.C. tarafından tehdit edildiği gerekçesiyle devletten koruma talep ettiğini ancak ret cevabı aldığını söyledi."

http://gazetekarinca.com/2017/12/yuzune-kezzap-atilan-kadin-devlet-10-gun-once-korumatalebimi-reddetmisti/ (erişim 02 Mayıs, 2018)

15 Örnek Olay: "Bursa'da T. U. adlı genç kadın, evlenme teklifini reddettiği ve şikâyeti üzerine savcılık tarafından koruma tedbirli uzaklaştırma kararı bulunan A. E. tarafından av tüfeği ile vuruldu. Genç kadın yaşamını yitirirken, aynı silahla intihara kalkışan A. E. ise ağır yaralı olarak hastaneye kaldııılı." "Televizyon (NTV)," NTV Radyo ve Televizyon Yayıncılığı A.Ş., erişim 02 Mayıs, 2018, https://www.ntv.com.tr/turkiye/evlenme-teklifini-reddetti-diyeolduruldu,Ep8eNYsRf0egtU72awVj_g.

${ }^{16}$ TÜíK'in konuya dair raporlarını ve uygulanan şiddetin farklı türlerini bir arada görmek için bkz. Veda Bilican Gökkaya, "Cam Tavan, Kadın ve Ekonomik Şiddet," The Journal of Academic Social Science Studies 26/II (2014): 371-383.
} 
tüm fertlerini, ${ }^{17}$ kendi öz çocuklarını ${ }^{18}$ topluca öldüren insanların haberleri gün geçtikçe artmaktadır.

4. Ekonomik Nedenler: Erkeğin işsiz kalması ya da ihtiyaçlarını karşılamada yeterli olmayan bir işte çalışması, onun psikolojisini bozmakta; dışardaki huzursuzluk nedenlerini ortadan kaldıramayan, problemlerini çözemediği için iç dünyasında huzursuz olan erkek; yemeği veya yapılan ütüyü beğenmeme gibi basit nedenleri bahane ederek şiddete başvurabilmekte, öfkesini kadına yöneltebilmektedir. Yani ev dışında uğradığı haksızlıkların faturasını kadına kesmek gibi bir kolaycılığa kaçan erkek, aslında kendisinin acziyetini ve ne kadar acınacak bir durumda olduğunu izhar etmektedir. ${ }^{19}$ Kadının bu durumu erkeğin aleyhine kullanması, eksikliklerini başa kakarak erkeği küçük düşürmesi durumunda erkeğin şiddete yönelmesinin arttığı da söylenebilir.

Yine kadının maddi durum ya da gücünün erkekten daha iyi olması da şiddete neden olan ekonomik etkenlerdendir. Erkek iş bulamazken kadının rahatlıkla iş bulması veya kadının maaşının erkekten daha yüksek olması gibi durumlarda erkek; çeşitli kılıflar uydurarak bulduğu işte çalışmaması veya yüksek maaşı işini terk etmesi gibi taleplerle kadının karşısına çıkmakta, olumlu cevap almadığında da şiddete yönelebilmektedir. ${ }^{20}$

Ekonomik nedenlerden biri de kadının iş hayatına atılmasıyla birlikte kendi ayaklarının üzerinde durması, ekonomik özgürlüğü sayesinde kendisini erkeğe bağlı hissetmemesidir. Çalışan kadın, kendisini erkeğe denk görmekte, kendisi de erkek gibi çalışarak yorulduğu ve eve yorgun geldiği için, toplumda normalde kadının görevi gibi görülen bazı ev işlerinde kendisine yardımcı

\footnotetext{
17 Örnek Olay: "Yaklaşık beş ay önce evlenen İ. ve Ş. Ş. çifti bir süredir şiddetli şekilde tartışıyorlardı. Tartışmalara daha fazla dayanamayan Ş. Ş. birkaç gün önce mahkemeye boşanmak için dilekçe verdi. Eşinin kendisinden boşanmak istediğini duyan İ. Ş. Yumaklar köyündeki eşinin ailesinin yaşadığı eve gitti. Burada bir süre eşiyle tartışan İ. Ş. av tüfeğiyle eşi Ş. Ş., kayınpederi N. (59) ve kayınvalidesi C. T.'ya ateş ederek öldürdü." "memurlar.net," MN Yazılım Medya Reklam A.Ş., erişim 03 Mayıs, 2018, https://www.memurlar.net/haber/439279/bosanmak-isteyen-esini-veesinin-ailesini-oldurdu.html.

${ }^{18}$ Örnek Olay: "Aydın'da, ayrı yaşadığı 20 yaşındaki H. Y.'u barışmak için görüşmeye çağıran F. Y. (30), eşini, çocukları 1 yaşındaki Y. P. Y. ile 3 yaşındaki G. Y.'u bıçaklayarak öldürdü.” "Cumhuriyet Gazetesi," Yenigün Haber Ajansı Basın ve Yayıncılık A.Ş., erişim 01 Haziran, 2018,

http://www.cumhuriyet.com.tr/haber/turkiye/443684/Aydin_da_koca_dehseti_Bosanmak_isteyen esini_ve_iki_cocugunu_katletti.html.

$\overline{19}$ Aktaş, "Sığınma Evinde Yaşayan Bir Grup Kadının Şiddet Deneyimleri Ve Baş Etme Yaklaşımları: Niteliksel Bir Çalışma," 814-815.

20 Örnek Olay: “Mersin'in Tarsus İlçesi'nde 47 yaşındaki M. G., tarlada çalışıp aile bütçesine katkıda bulunmak isteyen eşi 39 yaşındaki E. G. ile annesini korumak için araya giren oğlu 16 yaşındaki $R$. G.'i tabancayla vurarak öldürdü." 14.05.2010 tarihli Milliyet Gazetesi.
} 
olmasını eşinden talep etmektedir. Bu durumda erkek, eşinin bu haklı talepleriyle, ev işlerini yaptığında göreceği toplumsal tepkiler arasında kalmakta, yaşadığı çatışma huzursuzluğa, huzursuzluk da çoğunlukla psikolojik olmak üzere şiddete dönüşmektedir. Aslında burada ciddi bir çifte standart söz konusudur. Zira günümüz gençleri, erken yaşta ev ve araba sahibi olma, daha müreffeh bir yaşam sürdürme gibi nedenlerle, evlilikte, çalışan bayanı tercih etmektedir. Ancak bir yandan kadının kazandığı parayı kendi isteklerini gerçekleştirmede kullanırken, diğer yandan kadının gücünün sınırları olduğunu, onun bir makine değil insan olduğunu, yorulduğunu, ev işlerinin de en az işyerindekiler kadar hatta daha fazla yorucu olduğunu görmezden gelip, tüm işleri onun yapmasını istemektedir.

5. Kültürel Nedenler: İslam'ın yanlış anlaşılması ve anlatılması sonucu dinin de desteklediği izlenimi verilerek oluşturulan kültürde, erkeğin kadını dövmesi bir hak ve doğal bir olaymış gibi görülmekte; kadına uygulanan şiddet, lafı edilmeye bile değmeyen bir mevzu olarak kabul edilmektedir. İşin ilginç tarafı ise, kendisi yıllarca çeşitli şiddet türlerine maruz kalan kadınların, aynı şiddeti uygulaması için kendi oğullarını ya da erkek kardeşlerini yönlendirmesi; hatta bazen, bizzat bu şiddete iştirak etmesidir. ${ }^{21}$ Yaşanan boşanma vakalarında ya da aile içi şiddette 'kaynana' ve 'görümce' faktörü yadsınamayacak bir etkiye sahiptir.

Başlık kültürel etkenler olunca, şuna da dikkat çekmek gerekir: Bir insanın öğrenim seviyesinin yüksekliği, okumuş olması, asla onun daha az şiddet uyguladığı anlamına gelmez. Boşanma oranları şehirlerde, köylerdekinden daha yüksektir ve boşanma gerekçeleri incelendiğinde aile içi şiddetli geçimsizlik ve şiddete uğrama maddelerinin başı çektiği görülür. Adana ili genelinde yapılan bir araştırma, eğitimli insanların oturduğu mahallelerde yaşanan şiddet olaylarının daha fazla olduğunu ortaya koymuştur. ${ }^{22}$ TBMM'de 2011 yılında oluşturulan Meclis Komisyonu'nun raporuna göre, yükseköğrenim görmüş her altı erkekten biri, eşine fiziksel şiddet uygulamaktadır. Rakam, gerçekten azımsanacak gibi değildir. ${ }^{23}$

\footnotetext{
${ }^{21}$ Örnek olay için bkz. http://www.habervitrini.com/asayis/kaynana-ile-gorumce-odunla-gelinidovdu-670685 (erişim 06 Mayıs, 2018)

${ }_{22}$ Bkz. "TRT HABER," Türkiye Radyo ve Televizyon Kurumu Haber ve Spor Yayınları Dairesi Başkanlığı, erişim 06 Mayıs, 2018,

http://www.trthaber.com/haber/gundem/egitimli-kadin-daha-cok-siddet-goruyur-20568.html.

${ }^{23}$ Raporun detayları ve yorumu için bkz. Nesrin Akıncı Çötok, "Toplumsal Cinsiyet Rolü Dâhilinde Kadına Şiddet Olgusuna Karşı Kadın Algısı", International Journal of Social Sciences and Education Research 1/III (2015): 778-790.
} 
6. Kanunların Yetersizliği: İster beşerî olsun ister ilâhî, bütün hukuk sistemlerinde cezanın temel amacı, öncelikle caydırıcı olmak ve suça niyet eden kişiyi, eyleme dönüştürmeden önce bu niyetinden vazgeçirebilmektir. Suç işlendikten sonra cezanın uygulanmasının nedeniyse, işlenen suçun tekrarına engel olmak; bu cürmün işlenmesiyle mağdur olan bir taraf varsa, onun hakkını tazmin etmek, böylelikle toplumda düzenin hâkim olmasını sağlamaktır. ${ }^{24}$ Cezanın bir amacı da suçluyu, yaptığının yanına kalmayacağı noktasında eğitmek, böylelikle onu yeniden topluma kazandırmak ve hem suçlunun hem de onun şerrinden kurtulacak olan toplumun yararını temin etmektir. ${ }^{25}$ Yoksa suçludan intikam almak değil. ${ }^{26}$

Ancak günümüz Türkiye'sinde bu amaçların gerçekleşmesini sağlayacak bir suç-ceza dengesinin olduğundan, cezaların caydırıcılığından bahsetmek mümkün değildir. Hırsızlık yaparken suçüstü yakalanmış biri, çeşitli nedenlerle onu adliyeye getiren polis memurundan daha önce binayı terk edebilmektedir. Kanunlardaki boşluktan yararlanan ve tutuksuz yargılandığı bir dava için adliyeye gelen suçlunun, adliyede hâkimin çantasını çaldığı bile görülmüştür. ${ }^{27}$

Bir kadına hem işkence hem de tecavüz eden, sonra da onu öldüren birine verilen ceza, günde üç öğün yemek ikram edilen, kaloriferli cezaevlerinde müebbet istirahatten ibarettir. Cezanın 'müebbet' sıfatıyla muttasıf olması da gerçekten o suçlunun ölünceye kadar cezaevinde kaldığı anlamına gelmemektedir. İnfaz kanunu gereği belli bir süreyi tamamladıktan sonra, bu caniler serbest bırakılmaktadır. Şöyle ki: 5275 sayılı kanunun 107/2. maddesi gereğince sadece kadını değil, onunla birlikte bütün ailesini öldürmüş olsa bile bir hükümlü, aldığı ağırlaştırılmış müebbet hapis cezasının bihakkın 45 yıl olan süresinin 30 yılını infaz kurumunda (cezaevinde) çekmişse koşullu salıverilme hakkından yararlanır. ${ }^{28}$ Yani bir aileyi tümüyle yok etmenin cezası, sadece 30 yıl hapiste beklemekten ibarettir.

7. Beşerî Nedenler: Kumar, uyuşturucu, alkol vb. bağımlılıkları nedeniyle ev halkına karşı görevlerini ihmal etmesi sonucu kadınla yaşadığı

\footnotetext{
${ }^{24}$ Kemâluddîn Muhammed b. Abdilvahîd İbnu'I-Humâm, Şerhu fethi'l-kadîr, (Beyrut: Dâru'l-kutubi'lilmiyye, 1998), 4: 112.

${ }^{25}$ Cezanın tanımı, taşıması gereken özellikler için bkz. İbrahim Çalışkan, "İslâm Hukukunda Ceza Kavramı ve Hadd Cezaları," AÜIFD 31/I (1990): 367-397; İlhan Akbulut, "İslam Hukukunda Suçlar ve Cezalar," AÜIFD 52/l (2003): 167-181.

${ }^{26}$ Çalışkan, "İslâm Hukukunda Ceza Kavramı ve Hadd Cezaları", 370.

27 "İşyerinden hırsızlık yaptığı gerekçesiyle tutuksuz yargılandığı mahkemeye giden E. A. adlı sanık, duruşmasının bitmesinin ardından adliyede hırsızlık yaptı. E. A., Ağır Ceza Mahkemesi Başkanı'nın odasından çantasını çaldı." 17.11.2002 tarihli Hürriyet Gazetesi.

${ }^{28}$ Bkz. http://www.ceza-bb.adalet.gov.tr/mevzuat/5275.htm (erişim 10 Mayıs, 2018)
} 
sorunlar da erkeğin şiddete başvurmasında etkilidir. Yine kadınla erkek arasındaki fıtrî uyuşmazlıklar, ilerlemeyeceği çok açık olan evlilik birlikteliğini, aile baskısı, çocukların zarar görmesini engelleme isteği, mal paylaşımında haksızlığa uğrayacağı düşüncesi, çocukların velayeti konusunda yaşanılması muhtemel sorunlar, eşe duyulan bağımlılık gibi çeşitli nedenlerle sürdürmeye çalışılırken yaşanan gerilimler de birer şiddet nedenidir.

\section{B. Kur’anî Tedbirler}

Kur'an, yaratılışın merkezine insanı koyar. Onun en güzel şekilde yaratıldığını ${ }^{29}$ ve yeryüzündeki her şeyin de insan için hazırlandığını haber verir. ${ }^{30}$ Yani Kur'an için mahlûkatın en değerlisi ve en şereflisi, 'Yeryüzünün Halifesi'31 diye tanımladığı insandır. Hak ettiği değeri bulabilmesi için insanlar arasındaki her türlü ayrımcılığı reddeder ve yegâne üstünlüğün Allah'a karşı kulluktaki samimiyet olduğuna vurgu yapar. ${ }^{32}$ Yaratılmasının asıl gayesi olan kulluğunu $^{33}$ en güzel şekilde yerine getirebilmesi için, toplumsal hayatı düzenleyen kurallar koyar. Kur'an'ın belirlediği kurallar öylesine mükemmel bir suç-ceza dengesi oluşturur ki; bu denge, onları uygulayan toplumlarda benzerine az rastlanan bir tekâmül ve terakkiyi mümkün kılar.

Onun içine nazil olduğu cahiliye toplumunun hali dikkatle incelendiğinde; ne denli eşsiz bir dönüşüm sağladığı daha iyi anlaşılır. Kur'an, bir kızı olacağını öğrendiğinde dünyası yıkılan, ${ }^{34}$ hatta bir kısmı kendi kız çocuğunu diri diri gömen bir topluluktan, Asr-ı Saadet toplumunu çıkarmış, hayranlık uyandıran bir değişim ve ilerleme ortaya koymuştur. Tabi bu değişim, dönüşüm ve ilerlemeden kadın da nasibini almıştır. Daha önce insan olup olmadığı bile tartışılan kadın, ${ }^{35}$ Kur'an'da, erkeğin huzur kaynağ ${ }^{36}$ ve kendisine öf denilmesi

\footnotetext{
${ }^{29}$ et-Tîn, 95/4.

${ }^{30}$ el-Bakara, $2 / 29$.

31 el-Bakara, 2/30.

32 "Allah katında en değerli olanınız, O’na karşı gelmekten en çok sakınanınızdır." el-Hucurât, 49/13.

33 "Ben cinleri ve insanları, ancak bana kulluk etsinler diye yarattım." ez-Zâriyât, 51/56.

34 "Onlardan birine bir kız çocuğu müjdelendiği zaman üzüntüden yüzü simsiyah kesilir." en-Nahl, $16 / 58$.

${ }^{35} \mathrm{Bu}$ anlayış günümüzde bile varlığını sürdürmektedir. 23.02.2016 tarihinde Suudi Arabistan Riyad'da, Fehd Abdulaziz el-Ahmedî'nin moderatörlüğünde düzenlenen "Kadın insan mıdır" başlıklı seminer, Cahiliye Dönemi diyerek küçümsediğimiz devirden pek de ileride olmadığımızı bir kez daha ortaya koymuştur. Seminerin canlı yayını için bkz. https://www.youtube.com/watch?v=J2jbYk7Srys (erişim 11 Mayıs, 2018)

36 "Allah, sizi bir tek nefisten yaratan ve kendisi ile huzur bulsun diye eşini de ondan var edendir." el-A'raf, 7/189. "Kendileriyle huzura kavuşmanız için size kendi nefislerinizden eşler yaratıp aranızda sevgi ve merhamet var etmesi de O'nun ayetlerindendir." er-Rûm, 30/21.
} 
bile yasak olan ${ }^{37}$ kutsal bir varlık, bir 'eş' ve 'anne' olarak takdim edilir. Hz. Peygamber, cennetin annelerin ayakları altında olduğu haber verir. ${ }^{38}$ Bir başka hadiste de, "Kimin üç kızı olur da (onları yetiştirme konusunda) sabır gösterir, onları yedirir, içirir, giydirirse bu kızlar kıyamet günü onunla cehennem arasında bir perde olurlar"39 der, kız çocuğunun baba için ebedî kurtuluş vesilesi olduğunu haber verir. Bir diğer rivayette, Hz. Peygamber'in, “Kimin üç kızı veya üç kız kardeşi olur da onların sorumluluğunu üstlenir, onlara barınak olur ve onlara merhamet ederse cennete girer" dediği, bunun üzerine "Ya iki, (ikiye de aynı ödül var mı)" diye sorulduğu, onun "Evet ikiye de var" demesi üzerine "Ya bir" dedikleri, bire de olumlu cevap verdiği geçer. ${ }^{40}$

Kur'an'ın genel anlamda insanı, özel olarak da kadını korumaya yönelik tedbirlerine gelince onları şu başlıklar halinde ele almak mümkündür:

1. Yaşam Hakkını Koruma Altına Alması: Kur'an, bir insanın sahip olduğu haklar hiyerarşisinde en üstte yer alan yaşama hakkını, kısas ilkesi sayesinde korumaya alır. İnsan yaşamı kutsaldır ve hiç kimsenin ona müdahale yetkisi yoktur. Haksız yere birini öldürenin cezası, "Ey iman edenler! Öldürülenler hakkında size kısas farz kılındı. Hüre hür, köleye köle, kadına kadın (öldürülür). Ancak her kimin cezası, kardeşi (öldürülenin velisi) tarafından bir miktar bağışlanırsa artık (taraflar) hakkaniyete uymalı ve (öldüren) ona (gereken diyeti) güzellikle ödemelidir. Bu söylenenler, Rabbinizden bir hafifletme ve rahmettir. Her kim bundan sonra haddi aşarsa muhakkak onun için elem verici bir azap vardır"41 ayetiyle belirlenmiş; cana kıyanın, canına kıyılması emredilmiştir.

İdamın olmadığı, haksız yere bir cana değil, onlarca cana kıyanların, ağırlaştırılmış müebbet hapis adı altında hiçbir iş yapmadan yedirilip içirildiği bir ceza sisteminin caydırıcı olduğunu söylemek mümkün değildir. Birbirlerini hiç tanımayan insanların, trafikte yol verme gibi basit bir mesele yüzünden birbirini öldürebilmesi caydırıcılığın olmadığının ispatıdır. Bunu yapan kişi, kendisinin de öldürüleceğini bilse, böyle bir şeye cesaret edemez.

\footnotetext{
37 "Rabbin, kendisinden başkasına asla ibadet etmemenizi, anaya babaya iyi davranmanızı kesin olarak emretti. Eğer onlardan biri, ya da her ikisi senin yanında ihtiyarlık çağına ulaşırsa, sakın onlara "öf!" bile deme; onları azarlama; onlara tatı ve güzel söz söyle." el-İsrâ, 17/23.

38 "Cennet annelerin ayaklarının altındadır." Ebû Abdillah Muhammed b. Ca'fer el-Kadâî, Müsnedu'ş-Şihâb, (Beyrut: Müessesetu'r-risâle, 1986), 1/102.

39 İbn Mâce, Edeb, 3.

${ }^{40}$ Ebu Bekr b. Ebî Şeybe, el-Kitâbu'l-musannef fi'l-ehâdisi ve'l-âsâr, (Riyad: Mektebetu'r-ruşd, 1409), 5/222.

${ }^{41}$ el-Bakara, 2/178.
} 
Amacı, "Yaşayabilmek için öldürmekten vazgeçmeyi sağlamak" şeklinde Özetlenebilecek idam cezası, bir Arap atasözünde, "القتل أنفى للقتل - (Katili) Öldürmek, öldürmeyi engellemenin en kesin yoludur" şeklinde ifadesini bulmuştur. ${ }^{42}$ Buna dikkat çeken Kur'an-ı Kerim, "Ey akıl sahipleri! Kısasta sizin için hayat vardır" 43 buyurmaktadır. Gerçekten kısasta iki yönlü hayat vardır. Cinayete niyet edeni, bu niyetinden vazgeçirerek hem katilin hem de öldürmeyi düşündüğü kişinin yaşamını kurtardığı için iki tarafın da hayatiyetinin devamını sağlar. Katili de onun şerrinden emin olacak toplumu da korur. ${ }^{44}$

2. Kadın Erkek Ayrımını Reddetmesi: Kadına şiddet uygulayanların pek çoğu kadını kendisinden aşağıda gördüğü için yaptığı eylemi yadırgamamakta, kadına şiddeti doğal karşılamakta ve bunu kendi hakkı gibi telakki etmektedir. Şu ayette kadına yönelik üstten bakışa işaret edilir: "Dediler ki: 'Bu hayvanların karınlarındakiler sadece erkeklerimize ait olup kadınlarımıza haramdır.' Eğer ölü doğarsa o zaman hepsi onda ortaktır. Bu nitelemelerinden dolayı Allah onların cezasını verecektir. Çünkü O hikmet sahibidir, her şeyi bilendir."45 Ayette, canlı doğan hayvanın etini yeme hakkının Cahiliye Araplarınca sadece erkeğe verildiğine; ölü doğan leşin etinden yemeye layık görülerek kadının nasıl aşağılandığına bir vurgu vardır. ${ }^{46}$ Kur'an, böylesi bir zihniyete sonuna kadar karşı çıkar ve kadınla erkek arasında bir ayrım olmadığına pek çok ayette vurgu yapar:

"Erkek veya kadın, kim mümin olur da güzel amellerden işlerse, işte onlar cennete girerler. Zerre kadar da haksızlığa uğratılmazlar."47

“Mü'min erkekler ve mü'min kadınlar birbirlerinin dostlarıdır... Allah, mü'min erkeklere ve mü'min kadınlara, ebedî olarak kalacakları, içinden ırmaklar akan cennetler ve Adn cennetlerinde çok güzel köşkler va'detti."48

\footnotetext{
42 Ebu'l-Hasen Seyyiduddîn Ali b. Ebî Ali el-Âmedî, Gâyetu'l-merâm fî ilmi’l-kelâm, nşr. Hasen Mahmûd Abdullatîf, (Kahire: el-Meclisu'l-e'alâ li'ş-şuûni'l-İslâmiyye, trs.), 343.

43 el-Bakara, 2/179.

${ }^{44}$ Muhammed b. Muhammed Ebu's-Suûd, Irşâdu'l-akli's-selîm ilâ mezâya'l-kitâbi'l-kerîm, (Beyrut: Dâru ihyâi't-turâsi'l-arabî, ts.), 1/196.

${ }^{45}$ el-En'âm, 6/139.

${ }^{46}$ M. Hamdi Yazır, Hak Dini Kur'an Dili, (İstanbul: Eser Neşriyat, 1979), 3/2060-2061; Karaman vd.,

Kur'an Yolu, 2/477.

${ }^{47}$ en-Nisâ, 4/124.

${ }^{48}$ et-Tevbe, 9/71-72.
} 
"Ey insanlar! Şüphe yok ki, biz sizi bir erkek ve bir dişiden yarattık ve birbirinizi tanımanız için sizi boylara ve kabilelere ayırdık. Allah katında en değerli olanınız, O’na karşı gelmekten en çok sakınanınızdır."49

“Erkeklerin kadınlar üzerinde hakları olduğu gibi, kadınlarında erkekler üzerinde belli hakları vardır."50

"Rableri, onlara şu karşılığı verdi: "Ben, erkek olsun, kadın olsun, sizden hiçbir çalışanın amelini zayi etmeyeceğim. Sizler birbirinizdensiniz." 51

Tüm bu ayetler incelendiğinde Kur'an'ın cinsiyet temelli bir ayrımcılığı asla kabul etmediği, ancak yaratılıştan ve kendisine yüklenen görevlerden

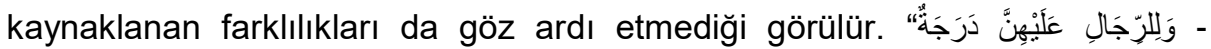
erkeklerin kadınlar üzerinde bir nebze üstünlüğü vardır"52 ayeti, bu farka gönderme yapar. İbn-i Abbas, bu üstünlüğün, kadına mehir vermesi ve kendi malından onun için harcaması nedeniyle olduğunu söylerken, Mücahid, erkeğin savaşması ve miras konusunda Yüce Allah tarafından kendisine iki kat pay belirlenmesi nedeniyle olduğunu bildirir. ${ }^{53}$ Kimileri de buradaki derecenin, erkeğin evin yöneticiliğini üstlenmesi, hem kadının hem de ailenin yararına olan her türlü tedbiri alması ve kendi malından onlar için harcaması manasında olduğunu “" 54 ayetinin bunun delili olduğunu iddia eder. Yurt savunması, savaş, maden ocakları ve inşaatta çalışma gibi tamamen bedene dayalı işleri üstlenmesi, yukarıda saydığımız harcamaları yapmak zorunda olması erkeği kadından ayıran yönlerdir. ${ }^{55}$ Görüldüğü gibi bunlar gerçek bir ayrım ya da üstünlük değil, yaratılıştaki farklılıktan ve üstlenilen sorumluluklardan kaynaklı olgulardır.

3. Kadına Mirastan Pay Ayırması: Kur'an'ın indiği dönemde kadının mirastan hiçbir hakkı yoktu. Mal, erkekler arasında bölüşülür, kadına, küçük çocuklara ve kızlara bir şey verilmezdi. Mesela Evs b. Sâbit el-Ensârî, geride üç kızını ve eşini bırakarak vefat ettiğinde, amcası çocuklarından kendisine mirasçı olan Süveyd ve Arfece isimli iki kişi gelerek onun tüm malını almışlar,

\footnotetext{
49 el-Hucurât, 49/13.

50 el-Bakara, 2/228.

51 Âlu İmran, 3/195.

52 el-Bakara, 2/228.

${ }^{53}$ Cemâluddîn Ebu'l-Ferec Abdurrahman b. Alî b. Muhammed el-Cevzî, Zâdu'l-mesîr fî ilmi't-tefsîr, nşr. Abdurrezzak el-Mehdî, (Beyrut: Dâru'l-kutubi'l-arabî, 1422), 1/200.

${ }^{54}$ en-Nisâ, 4/34.

${ }^{55}$ Ahmed b. Mustafa el-Merâğî, Tefsîru'l-Merâğî, (Kahire: Şeriketu mektebetu ve matbaatu Mustafa el-Bâbî, 1946), 2/167.
} 
karısına ve yetim kalan kızlarına bir şey bırakmamışlardı. ${ }^{56}$ Bir diğer rivayete göreyse geride bir oğlan, bir kız ve eşini bırakarak vefat etmişti ve oğlu tüm mirasa el koymuş, annesine ve kız kardeşine hiçbir şey vermemişti. ${ }^{57}$ Evs'in hanımı, Hz. Peygamber'e giderek başından geçeni anlattı. Hz. Peygamber, Allah'ın bu konudaki hükmü belli oluncaya kadar sabretmesini ve evine dönmesini söyledi. Derken şu ayet nazil oldu: "Ana, baba ve akrabaların miras olarak bıraktıklarında erkeklerin hissesi vardır. Kadınların da ana, baba ve akrabaların bıraktıklarında hisseleri vardır. Bunlar, az olsun çok olsun, farz kılınmış bir hissedir." ${ }^{8} \mathrm{Bu}$ ayetle, kadınların da mirastan bir hakları olduğu belirtildi. Devamındaki ayetlerde erkeklerin tamahkâr davranmamaları ve bu kadınlarla empati kurmaları istenerek, "Kendileri, geriye zayıf nesiller/çocuklar bıraktıkları takdirde, onlar hakkında endişeye kapılanlar, (yetimler hakkında da) ürperip korksunlar."59 denildi. Rahmet duyguları harekete geçirilen erkeklere, 'ölen siz, geride kalanlar da sizin çocuklarınız olabilir' gerçeği hatırlatıldı, empati kurmaları istendi. 60

Her zaman rahmetle azabı dengede tutan Kur'an, bununla da yetinmeyip, yetimlerin haklarını yiyenleri çok ağır bir şekilde tehdit ederek şöyle devam etti: "Yetimlerin mallarını haksız yere yiyenler, ancak ve ancak karınlarını doldurasıya ateş yemiş olurlar ve zaten onlar çılgın bir ateşe (cehenneme) gireceklerdir."61 Buradaki tehdit, iki boyutluydu. Hem yetimlerin hakkı olan malı alanlar, hem de yanlarına sığınan yetimlerin malını haksızca yiyenler ayette hedef alınıyordu. Bir yandan, "Siz ölseniz de geride bıraktığınız çocuklarınız beş parasız ortada kalsa hoşunuza gider miydi?" hatırlatması yapılıyor, diğer yandan da yaşları küçük, akılları ermez olduğu için büyür de elimden alır korkusuyla yetimlerin mallarını pervasızca yiyenler tehdit ediliyordu. ${ }^{62}$ Ancak hâlâ bir kapalııı vardı. Zira kadının hakkının ne kadar olduğu, alacağı miktar açıklanmamıştı. "Allah size, çocuklarınız hakkında, erkeğe, kadının payının iki misli (miras vermenizi) emreder. (Çocuklar) ikiden fazla kadın iseler, ölünün bıraktığının üçte ikisi onlarındır. Eğer yalnız bir kadınsa yarısı onundur. Ölenin çocuğu varsa, ana-babasından her birinin

\footnotetext{
56 Ebu Abdillah Muhammed b. Ömer Fahruddîn er-Râzî, Mefâtihu'l-gayb, (Beyrut: Dâru ihyâi'tturâsil'l-arabî, 1420), 9/502.

57 Nasr b. Muhammed b. Ahmed es-Semerkandî, Bahru'l-ulûm, (Beyrut: Dâru'l-kutubi'l-ilmiyye, 2010), 1/283.

58 en-Nisâ, $4 / 7$.

59 en-Nisâ, $4 / 9$.

60 İbnu'l-Cevzî, Zâdu'l-mesîr, 1/376.

61 en-Nisâ, 4/10.

62 Nâsıruddîn Ebû Saîd Abdullah b. Ömer el-Beydâvî, Envâru't-tenzîl ve esrâru't-te'vîl, nşr. Muhammed Abdurrahman el-Maraşlı, (Beyrut: Dâru ihyâi't-turâsi'l-arabî, 1418), 2/62.
} 
mirastan altıda bir hissesi vardır. Eğer çocuğu yok da ana-babası ona vâris olmuş ise, anasına üçte bir (düşer)."63 ayeti de bu kapalılığı giderdi ve keyfiliğe izin vermeyecek net bir anlatımla ister anne olsun, ister eş, isterse de ölenin kızı, kadının mirastan alacağı oranları belirledi.

Bir başka ayette de "Kadınlar hakkında senden fetva isterler. De ki: Onlar hakkındaki fetvayı size Allah veriyor: Yazılmıs hakları olan mirası kendilerine vermediğiniz ve nikâhlanmayı istemediğiniz öksüz kızlar ve zavallı çocuklara ve bir de yetimlere adaletle davranmanız hakkında Kitap'ta size okunan ayetler vardır."64 denilerek, kadınların işlerini bizzat Allah Teâlâ'nın üstlendiği haber verildi ve onlar hakkında Kur'an'ın emrine göre davranmayanlar uyarıldı. Cahiliye Döneminde, bazı açgözlüler, "Ben bu kızı da babasından kalan tüm malı da aldım" demek suretiyle zorla onlara sahip olabiliyorlardı. Yine bir kız yetimse, nikâh yapmadan ve mehir vermeden ona sahip olabiliyordu. İslam bu tür şeylerin önüne geçti ve devlet eliyle kadınları koruma altına aldı. Öyle ki Hz. Ömer, yetim bir kıza veli olan biri kendisine geldiğinde bakardı: Eğer kız zengin ve güzelse, adama 'Onu bir başkasıyla, kız açısından senden daha hayırlı olan biriyle evlendir' derdi. Böylelikle o adamın, kıza zorla sahip olmasını engellerdi. 65

Bir de kendisiyle evlenemeyecek olanların yetimlere veli olması durumu vardır. Mesela ölen kardeşin kızının ya da oğlunun velayetini amcanın üstlenmesi gibi. Kur'an bu durumda olanları da koruma altına alarak şöyle der: "Yetimleri deneyin. Evlenme çağına (buluğa) erdiklerinde, eğer reşid olduklarını görürseniz, mallarını kendilerine verin. Büyüyecekler (ve geri alacaklar) diye israf ederek ve aceleye getirerek mallarını yemeyin. (Velilerden) kim zengin ise (yetim malından yemeğe) tenezzül etmesin. Kim de fakir ise, aklın ve dinin gereklerine uygun bir biçimde (hizmetinin karşılığı kadar) yesin."66

Görüldüğü üzere Kur’an, tüm ihtimalleri hesaba katarak kadın ve kızların miras haklarını koruyan ilkeler koymuştur. Burada şöyle bir itiraz getirilebilir: Kızın miras hakkı neden erkeğin yarısı? Bu haksızlık değil mi? Öncelikle şunu belirtelim ki, Kur'an onlara pay vermeden önce, hiçbir şey almıyorlardı. İlk kez Kur'an sayesinde mal alır hale geldiler. Bir de İslam'ın kadınla ilgili düzenlemelerini bütüncül olarak incelemeden yorum yapmamak gerekir. İslam,

\footnotetext{
63 en-Nisâ, 4/11.

64 en-Nisâ, 4/127.

${ }^{65}$ Ebu'l-Kâsım Muhammed b. Amr b. Ahmed ez-Zemahşerî, el-Keşşâf an hakâiki ğavâmidi't-tenzîl, (Beyrut: Dâru'l-kitâbi'l-arabî, 1407), 1/570.

${ }^{66}$ en-Nisâ, 4/6.
} 
koyduğu diğer kurallarla kadının hakkını, ona pozitif ayrımcılık yapacak tarzda koruma altına almıştır. O kurallar da incelenip, ona göre değerlendirme yapılırsa, kadına bir haksızlık yapılmadığı görülür.

Öncelikle, kadın kendi babasının mirasından kardeşinin yarısı kadar mal alıyorsa da onun kocası da kendi babasından kalan maldan iki kat miras alıyor. Dolayısıyla bir dengeleme buradan gelir.

İkincisi, mirastan iki kat mal alan erkek, kız kardeşinin eşinin ölmesi veya boşanması ya da kızın hiç evlenmemiş olması gibi durumlarda, babaları öldüğü için gidecek başka yeri olmayan kadının zorunlu velisidir ve ömür boyu ona bakmakla, her türlü ihtiyacını karşılamakla mükelleftir. Yani burada kadın, kendi soyundan ona en yakın olana, kardeşine, zimmetlenmekle ömür boyu sigortalanmış olmaktadır.

Üçüncüsü, evlilik esnasında kadına mehir vermek, yeni kurulacak olan evin eşyalarını satın almak, düğün masraflarını karşılamak, evlilik boyunca hem kadının hem de bu evlilikten dünyaya gelecek olan çocukların nafakalarını; yeme, içme, giyinme, barınma gibi tüm ihtiyaçlarını temin etmek, eğer bakıma muhtaçlarsa ve kendi iaşelerini, idarelerini sağlayamıyorlarsa anne-babaya bakmak ve onların her türlü ihtiyacını karşılamak erkeğin zorunlu görevidir. Buna, onların yaşaması için gerekli olan her şey dâhildir. Sağlık giderlerinden tutun da ölümleri halinde tekfin, teçhiz ve defin masraflarına varana kadar tüm masrafları erkek evlat karşılar.

Yine erkeğin asabesinden biri, bir cinayet işler de diyet ödenmesi gerekirse âkile sıfatıyla bu diyetten payına düşeni ödemek de erkeğin görevidir. Nisa suresi 34. ayet-i kerime, “...erkekler kendi mallarından harcamaktadırlar" diyerek bu duruma dikkat çeker. Her nimetin bir külfetinin de olacağı, nimetkülfet dengesinin zorunluluğu aşikârdır. Bu saydıklarımızın hiç biriyle mükellef olmayan kadının mirastan erkeğin yarısı kadar pay almakla haksızlığa uğradığını söylemek, haksızlık olur. ${ }^{67}$

4. Kadına Mehir Verilmesini Emretmesi: Kadın, kendisine evlenme teklif eden erkeğin bu teklifini kabul edip de nikâhı yaptığı anda, sınırlarını nikâhtan önce kendi belirleyeceği bir meblağı, mehri, hak eder. Eğer miktarı belirlemişse bu mehre, mehr-i müsemmâ adı verilir. Meblağ belirlemeyi unutmuş ya da böylesi bir şeyi konuşmak istememişse, örfen onunla aynı

${ }^{67}$ Râzî, age, IX/508-511; İbnu'I-Cevzî, age, I/377-379.

ÇÜiFD, 2018, cilt: 18, sayı: 2, ss. 958-994. 
konumda olanlara ödenen mehir kadar bir mehir kendisine ödenir ki bu durumda da mehir, mehr-i mis/ olarak adlandırılır. ${ }^{68} \mathrm{Bu}$, onun geleceğini teminat altına almaya yönelik bir tedbirdir.

Kadın, evlilikle birlikte mesai kavramı olmadan gece-gündüz çalışacak; eşinin, çocuklarının ve evin ihtiyaç duyduğu hizmetleri yerine getirecek, normal çalışanlara sunulan hafta sonu tatili, bayram tatili, yaz tatili, yıllık izin gibi hiçbir haktan da yararlanamayacaktır. Hatta hastalanması bile bir şey ifade etmeyecek, eli ayağı tuttuğu sürece hasta haliyle kalkıp aynı hizmetleri sürdürecektir. Tüm bu yoğunluk içerisinde, kendi geleceğini garantiye alacağı ek bir iş yapma imkânı da çoğunlukla bulamayacaktır. Dolayısıyla işler ters gider de evliliği sonlanırsa ya da eşi vefat ederse, mirasçıların paylaşımından uzak, sırf kadına ait bir maddi karşılığın olması kadın için hayati öneme sahiptir. Evlenme karşılığında bir bedel ödenmesi, İslam harici toplumlarda da mevcuttur. Mesela Yahudilerdeki drahoma geleneğinde, evlenecek kadın, erkeğe bir bedel ödemektedir. Aynı kelime, Avrupa ülkeleri ile Türkiye'deki Rumlar ve Ermenilerde de kadının erkeğe ödediği başlık parasını ifade eder. ${ }^{69}$ Yani kadın, bu kadar emeğin ve çalışmanın üstüne bir de bedel ödemektedir. Yine Eski Türk geleneğinde kalın, ${ }^{70}$ diğer bazı toplumlarda dowry denilen gelenekte, yaygın adıyla başlık geleneğinde, erkek tarafı kızın ailesine bir ödeme yapmaktadır ve kız, bundan istifade edememektedir. ${ }^{71}$ İslâm'ın emrettiği mehirde ise, ödeme doğrudan kadına yapılmakta, hiç kimse onun bu hakkına dokunamamaktadır.

Mehirle alakalı bazı detaylar vardır ki, bunların mutlaka bilinmesi gerekir. Öncelikle her ne kadar mehir, mehr-i muaccel (peşin ödenen) ve mehr-i müeccel (ödenmesi için süre tanınmış) olmak üzere ikiye ayrılmışsa da kadın, tüm mehrini peşin isteme hakkına sahiptir. ${ }^{72}$ Mehrin, muaccel/peşin mi yoksa müeccel/ertelenmiş mi olacağına karar verecek olan, kadının kendisidir.

Mehir, günümüz yasalarının boşanma esnasında kadına sağladığı tazminat hakkından çok daha değerlidir. Zira tazminatta, miktarı hâkim belirlemektedir. Mehirde ise miktarı belirleyen kadının kendisi, rıza gösteren de

\footnotetext{
${ }^{68}$ Ebu'l-Hasen Alî b. el-Huseyn es-Suğdî, en-Nutefu fi'l-fetâvâ, nşr. Salahuddîn en-Nâhî, (Beyrut: Dâru'l-Furkân, 1984), 1/297.

69 Uğur Özcan ve Murat Gökhan Dalyan, "19. yy'da Rumlarda ve Arnavutlarda Evlilik Müessesesinde Başlık Uygulamaları", History Studies 3/III (2011): 319-336.

${ }^{70}$ Mehmet Mandaloğlu, "İslamiyet’ten Önce Türklerde Aile Hukuku," Türkiyat Araştırmaları Dergisi 33 (2013): 133-159.

${ }^{71}$ http://www.islamveihsan.com/mehir-nedir-mehir-neden-verilir.html (erişim 01 Haziran, 2018)

72 Muhammed b. Muhammed, el-İnâye şerhu'l-hidâye, (Beyrut: Dâru'l-Fikr, trs), 4/382.
} 
erkektir. Yani iki tarafın rızasıyla gerçekleşir. Yine tazminat, boşanma sonrası ödenmesi istenen bir paradır. Yani eşler arasındaki her türlü sevgi ve saygının bittiği, boşanacak kadar biri birlerinden soğudukları bir dönemde. Bu nedenle söz konusu tazminatı ödemek erkeğe çok ağır gelebilmekte, devlet eliyle bu meblağı ödemeye zorlandığında kadına ve ailesine çeşitli zararlar verebilmekte ya da muvazaalı borçlanmalarla kendisine icra koydurarak kadının bu parayı almasını engelleyebilmektedir.

Hâlbuki mehir, erkeğin kadına ulaşmayı arzuladığı, onunla hayatını birleştirmeyi istediği bir zamanda, evliliğin başında, gönül rızasıyla verilen bir meblağdır. Buna dikkat çeken bir ayette, "Kadınlara mehirlerini gönül hoşluğuyla verin."73 denir. Yine bir başka ayette, kadına verdiği mehri elinden almak için ona baskı yapmanın erkeğe haram olduğuna dikkat çekilerek şöyle denir: "Ey iman edenler! Kadınlara zorla varis olmanız size helal değildir. Verdiğiniz mehrin bir kısmını kurtaracaksınız diye, onları sıkıştırmanız da helal değildir."74 Yine tazminat, evliliğin bitmesinden sonra elde edilen gecikmiş bir hak olduğu halde mehir, evliliğin başında alınabilir ve kadın, onu, evliliğin devam ettiği yıllar boyunca çeşitli şekillerde yatırıma dönüştürerek artmasını sağlayabilir.

Mehir, nikâh akdinin yapılmasıyla birlikte kadının hak ettiği bir meblağdır. Nikâh akdi yapılır ve bir mehir belirlenir de evlilik gerçekleşmeden, yani taraflar zifafa girmeden önce boşanma vaki olursa; erkek, belirlenen mehrin yarısını kadına ödemek zorundadır. Bunu emreden ayet şöyledir: "Eğer onları, kendilerine dokunmadan önce boşar ve mehri de belirlemiş bulunursanız, o zaman borç, o belirlediğiniz miktarın yarısıdır. Ancak kadınlar veya nikâh akdini elinde bulunduran veli bağışlarsa başka. Ey erkekler! Sizin bağışlamanız takvaya daha yakındır. Aranızda erdemli davranmayı unutmayın. Şüphesiz ki Allah, her ne yaparsanız hakkıyla görür."75

$\mathrm{Bu}$ ayette kadın lehine pek çok incelik bir aradadır. Öncelikle, Bakara suresinde ${ }^{76}$ genel anlamda boşanılan kadınlara verilmesi istenen mut'a (maddi destek) hakkı, her ne kadar karı-koca olmamışlarsa da bu kadın için de geçerlidir ve erkek, gücü dâhilinde kadına, kalan yaşamında rahat etmesini

\footnotetext{
73 en-Nisâ, $4 / 4$.

74 en-Nisâ, 4/19.

75 el-Bakara, 2/237.

76 "Boşanmış kadınların örfe göre geçimlerinin sağlanması onların hakkıdır. Bu, Allah'a karşı gelmekten sakınanlar üzerinde bir borçtur." el-Bakara, 2/241.
}

ÇÜiFD, 2018, cilt: 18, sayı: 2, ss. 958-994. 
sağlayacak bir ödeme yapar. ${ }^{77}$ Bakara 237. ayette ise, kadının genel anlamda maddi yönden erkekten daha zayıf oluşu göz önüne alınarak, evlilik gerçekleşmediği halde ona maddi bir hak sunulmuş, mehrin yarısını alması sağlanmıştır. Ancak bu durum genel geçer değildir. Bazen kadının durumu iyi olabileceği için bu haktan vazgeçme iradesi de kadına verilmiş ve isterse mehri almayabileceği bildirilmiştir. Yine üçüncü bir durum daha hesaba katılmış, kadının bu verilecek yarım mehirden daha fazlasına ihtiyacı olabileceği düşünülerek "Ey erkekler! Sizin bağışlamanız takvaya daha yakındır."78 denilerek, mehrin yarısını değil de imkânları el veriyorsa tamamını ödemeleri tavsiye edilmiştir. ${ }^{79}$ Son olarak da boşanma olsa bile hâlâ din kardeşi olmaları hasebiyle aralarında fitneye izin vermemeleri ve karşılıklı olarak erdemli davranmaları tavsiye edilmiştir. " " الا تنسوو - unutmayın" hitabı, erkeklereymiş gibi görünse de Hz. Ali'nin bu ayeti تناسو ' لا لتنوو şeklinde müşareket/işteşlik ifade eden tefâul babından okuması, hitabın hem erkeklere hem de kadınlara yönelik olduğunu, iki taraftan da erdemli davranmasının talep edildiğini gösterir. ${ }^{80}$

Nikâh akdi yapılır, fakat mehir belirlenmemiş olur da boşanma gerçekleşirse, "Eğer kadınları, kendilerine dokunmadan veya onlara bir mehir takdir etmeden boşarsanız (bunda) size bir vebal yoktur. Şu kadar ki onlara (mal verip) faydalandırın. Eli geniş olan hâline göre, eli dar olan da haline göre ve güzellikle faydalandırmalıdır. Bu, iyilik yapanlar üzerine bir borçtur" ayeti gereği, kişinin gücü ve toplumda cari olan örf dikkate alınarak kadının yararı gözetilir. ${ }^{81}$ Onu memnun edecek bir meblağ kendisine ödenir.

Mehirle ilgili önemli detay da şudur: Eğer erkek, bir başkasıyla evlenmek istediği için evlilik birlikteliğini sona erdirirse, ilk eşine verdiği mehirden hiçbir şeyi geri alamaz: "Eğer bir eşinizi boşayıp yerine başka bir eş almak istiyorsanız, önceki eşinize yüklerle mehir vermiş olsanız bile içinden hiçbir şey geri almayın."82 İlk eşin herhangi bir kabahati ve günahı olmadığı halde, sırf kendi zevki ve keyfi için onu boşamayı düşünen birine, onunla zorla birlikte yaşa demek anlamsızdır. Ancak yaptığının cezasını, verilen mehri elinden almak

\footnotetext{
77 Ebu Muhammed Abdulhakk İbn Atiyye el-Endelûsî, el-Muharreru'l-vecîz fî tefsîri'l-kitâbi'l-azîz, nşr. Abdusselâm Abduşşâfî Muhammed, (Beyrut: Dâru'I-kutubi'l-ilmiyye, 1422), 1/320.

${ }^{78}$ el-Bakara, 2/237.

79 Celâluddîn Muhammed b. Ahmed el-Mahlî, Celâluddîn Abdurrahman b. Ebî Bekr es-Suyûtî, Tefsîru'l-Celâleyn, (Kahire: Dâru'l-hadîs, ts), 52.

${ }^{80}$ Ebu Zeyd Abdurrahman b. Muhammed es-Seâlibî, el-Cevâhiru'l-hisân fî tefsîri'l-Kur'ân, (Beyrut: Dâru ihyâi't-turâsi'l-arabî, 1418), 1/477.

81 Karaman vd., Kur'an Yolu, 1/375.

82 en-Nisâ, 4/20-21.
} 
suretiyle kadına ödettirmesi de kabul edilemez. Bu nedenle ayet, mehrin zerresine bile dokunulmayacağını net bir şekilde bildirmiştir. ${ }^{83}$

5. Nafaka Hakkı Sağlaması: Kur'an, kadına birkaç çeşit nafaka takdir etmiştir. Birincisi, evlilik devam ettiği müddetçe erkek tarafından karşılanacak olan nafakadır ki kadının yeme, içme, giyinme, barınma, tedavi olma gibi her türlü ihtiyacı bu kapsamdadır. Kadın çok zengin olsa bile, bu tür ihtiyaçlarını kendi cebinden karşılamaya zorlanamaz. Evlilik devam ettikçe bunlar erkeğe aittir.

İkincisi, boşanan kadının emzikli çocuğu varsa ve boşanma nedeniyle çocuğun mağdur olmasını istemez de emzirme süresini tamamlamaya karar verirse, bu süre zarfında kadının nafakası erkeğe aittir ve ihtiyaçlarını erkek karşılar. Bunu emreden ayet şöyledir: "Emzirmeyi tamamlatmak isteyen (baba) için, anneler çocuklarını iki tam yıl emzirirler. Onların örfe uygun olarak beslenmesi ve giyimi baba tarafına aittir." ${ }^{44}$ Ancak bu emzirmeyi tamamlama, tarafların rızasına bağlıdır, bir zorunluluk değildir. Çeşitli gerekçelerle bu süre tamamlanmayabilir: "Eğer ana ve baba birbiriyle görüşerek ve karşılıklı anlaşarak çocuğu memeden kesmek isterlerse, kendilerine günah yoktur. Çocuklarınızı (sütanne tutup) emzirtmek istediğiniz takdirde, sütanneye vermekte olduğunuzu iyilikle teslim etmeniz şartıyla, üzerinize günah yoktur."85

Ayetteki bir incelik de şudur: Neseb olarak çocuk babaya ait olmakla beraber boşanma sonrası anne emzirmek isterse, çocuk elinden alınmakla kadına zarar verilmez: "Hiçbir anne, çocuğundan dolayı zarara uğratılmasın." Yani çocuktan mahrum bırakılmakla anneyi cezalandırma yoluna gitmek, bir Müslümana haramdır. ${ }^{86}$

Üçüncüsü, boşanmış kadına boşanma sonrası verilecek olan nafakadır ki, bunun ölçüsü örftür. Yani örfe göre kadının hayatını sürdürebileceği asgari miktarda bir nafaka vermek erkeğe düşer: "Boşanmış kadınlar için de meşru ve geleneğe uygun şekilde bir meta' (nafaka hakkı) vardır ki verilmesi, Allah'tan korkanlar üzerine bir borçtur."87 Ayetin olayı, takvanın bir gereği olarak sunması, Yüce Allah'ın emir ve tavsiyelerine uyan, yasak ve uyarılarından uzak

\footnotetext{
${ }^{83}$ Muhammed Reşid b. Ali Rıza, Tefsîru'l-menâr, (Kahire: el-Hey'etu'I-mısriyyetu'l-âmmetu li'l-kitâb, 1990), 4/375.

${ }^{84}$ el-Bakara, 2/233.

85 el-Bakara, 2/233.

86 Muhammed Cemâluddîn el-Kâsımî, Mehâsinu't-te'vîl, nşr. Muhammed Bâsil Uyûnu's-Sevd, (Beyrut: Dâru'l-kutubi'l-ilmiyye, 1418), 2/154.

${ }^{87}$ el-Bakara, 2/241.
} 
duran herkesin bunu güzellikle, gönül hoşluğuyla yapmasını ve kendisini o dairede görmesini temin içindir. ${ }^{88}$

Dördüncüsü, eşleri ölen kadınlara yönelik nafakadır. Bunu emreden ayet şöyledir: "Içinizden ölüp geriye dul eşler bırakan erkekler, eşleri için, evden çıkarılmaksızın bir yıla kadar geçimlerinin sağlanmasını vasiyet etsinler."89 Ölen insan vasiyette bulunamaz. Burada ölenden kasıt, ölüme yaklaşandır. Ayet, kadının kendi iradesiyle çıkması durumu hariç, bir yıla kadar erkeğin evinde kalmasını, çıkarılmamasını, erkeğin malından da bir yıl kadına yetecek kadar nafaka ayrılmasını ve bu miktardaki malın diğer mallar gibi mirasçılar arasında taksim edilmemesini emrederek, kadını bir yıllığına kalacak yer ve geçimlik noktasında endişe etmekten kurtarmaktadır. ${ }^{90}$ Kadın zaten dört ay on gün kocasının ölümü nedeniyle iddet beklemek zorundadır ve yeni bir evlilik yapamaz. ${ }^{91}$ Dolayısıyla gerek bu dört ay on günlük süre gerekse de kalan sekiz ay ayetle teminat altına alınmıştır.

6. Evlenme ve Boşanmayı Kurallara Bağlaması: Kur'an'dan önce toplumda hâkim olan evlenme ve boşanma kuralları fıtrata uygun değildi. Ancak İslam, yaptığı değişikliklerle fıtrat dini olduğunu bir kez daha ortaya koydu. Evliliğin, hem tarafların hem de bu evlilikten doğacak çocukların haklarının korunması için şahitler huzurunda yapılmasını, kadına mehr-i müsemma veya mehr-i misl ödenmesini, evlilik süresince kadının her türlü ihtiyacının erkek tarafından karşılanmasını zorunlu hale getirdi. Insanların üvey anneleriyle evlenmelerini ${ }^{92}$ ve aynı anda iki kız kardeşle evlenmeyi, ${ }^{93}$ yine bir kadını kendi halası ve teyzesiyle birlikte nikâhlayabilmeyi yasaklayarak bu iğrenç gelenekleri kaldırdı. ${ }^{94}$

\footnotetext{
${ }^{88}$ Alâuddîn Ali b. Muhammed el-Hâzin, Lubâbu't-te'vîl fî meâni't-tenzîl, (Beyrut: Dâru'l-kutubi'lilmiyye, 1415), 1/176.

89 el-Bakara, 2/240.

90 Muhammed el-Emîn b. Abdillah el-Ermî, Tefsîru Hadâiku'r-ravhi ve'r-reyhân, (Beyrut: Dâru tavki'n-necât, 2001), 3/374.

91 el-Bakara, 2/234.

92 "Babalarınızın evlenmiş olduğu kadınlarla evlenmeyin. Ancak İslâm gelmezden önce yapılanlar geçmişte kalmıştır. Bu kesinlikle utanç verici bir iştir, çirkin bir şeydir ve kötü bir yoldur." en-Nisâ, $4 / 22$.

93 "Size şunlarla evlenmek haram kılındı: Analarınız, kızlarınız, kız kardeşleriniz, halalarınız, teyzeleriniz, erkek kardeş kızları, kız kardeş kızları, sizi emziren sütanneleriniz, sütkız kardeşleriniz, karılarınızın anneleri, kendileriyle zifafa girdiğiniz karılarınızdan olup evlerinizde bulunan üvey kızlarınız, -eğer anneleri ile zifafa girmemişseniz onlarla evlenmenizde size bir günah yoktur- öz oğullarınızın karıları, iki kız kardeşi (nikâh altında) bir araya getirmeniz. Ancak geçenler (önceden yapılan bu tür evlilikler) başka. Şüphesiz Allah çok bağışlayıcıdır, çok merhamet edicidir." en-Nisâ, $4 / 23$.

94 Türkiye Diyanet Vakfı İslam Ansiklopedisi, Fahrettin Atar, (İstanbul, TDV Yay., 2006), "Muharremât" maddesi.
} 
Kur'an'ın indiği dönemde Araplarda boşama için bir sınır olmadığı gibi, boşanan kadının beklemesi zorunlu olan bir iddeti de yoktu. Kadın, erkeğin elinde bir oyuncak mesabesindeydi. Erkek, zulmetmek için onu tekrar tekrar boşuyor, kadının süresinin dolmasına ve nikâhın bitmesine az bir zaman kala tekrar ona döndüğünü ilan ederek kadına bir kurtuluş imkânı bırakmıyordu. Böylelikle ne boşuyordu ki kadıncağız yeni bir yuva kursun ne de ona kocalık yapıyordu. Kadının maddi manevi hiçbir ihtiyacını karşılamayarak ona azap çektiriyordu. Yine boşanan kadının bir iddetinin olmaması, isterse boşandığı gün bir başkasıyla evlenebilmesi neseplerin karışması gibi bir tehlike doğuruyordu. ${ }^{95}$

Kur'an, evlenme ve boşanmayı kurallara bağlayarak kadını bu işkenceden kurtardı. Erkeğin sınırsız olan boşama hakkını 3 talakla sınırladı ve gerekçe ne olursa olsun bir erkeğin kadını üç kez boşaması durumunda nikâhın sonlanacağını hükme bağladı: "Boşamak (talak) iki defadır. Ondan sonrası ya iyilikle tutmak veya güzellikle salmaktır.. Eğer kadını bir daha boşarsa (üçüncü kez), bundan sonra artık başka bir kocaya varıncaya kadar ona helâl olmaz."96 Görüldüğü gibi erkek farklı zamanlarda kadını üç kere boşamışsa, artık o nikâh sona erer.

Burada şuna da dikkat çekmek gerekir: İslam, bir yandan kadını erkeğin elinde bir oyuncak olmaktan çıkarıp, talakı üçle sınırlayarak kadına yapılan eziyetin önüne geçmiş; diğer yandan da müeccel olan mehrin, boşanmayla birlikte muaccele dönüşmesi ve hemen ödenmesi, o kadının bir başka erkekle evlenmedikçe eski kocasına haram olması gibi tedbirler koyarak boşanma konusunda erkeği defalarca düşündükten sonra adım atmaya mecbur kılmıştır.

Yine boşanan kadına üç aylık bir iddet sınırı koymuş, bu süreyi doldurmadan başkasıyla evlenmesini yasaklamıştır: "Boşanmış kadınlar kendi kendilerine üç ay hâli (hayız veya temizlik müddeti) beklerler."97 Neseplerin karışma riskini ortadan kaldırmak için burada hamile olmayan ancak adet görebilen kadınlara seslenilmiştir. Ayet kadına, kocanın ric'at hakkını ortadan kaldırma veya çocuğu kendi babası dışında birine nispet etme konusunda dikkatli olmasını emrederek bu konuda dürüst davranmanın bir iman meselesi olduğuna dikkat çekmiştir.98

\footnotetext{
${ }^{95}$ Reşid Rıza, Tefsîru'l-menâr, 2/302.

${ }^{96}$ el-Bakara, 2/229-230.

97 el-Bakara, 2/228.

98 Ebu Muhammed Mekkî b. Ebî Tâlib, el-Hidâyetu ilâ bulûği'n-nihâye, (eş-Şârika: Mecmûatu buhûsi'l-kitâbi ve's-sünne, 2008), 1/758.
} 
7. Namus Kavramını Hem Erkek Hem de Kadın İçin Ele Alması: Kur'an, namus konusunda kadınla erkek arasında bir fark görmez. Yukarıda şiddetin nedenleri başlığında değindiğimiz üzere erkek namussuzluk yaptığında hoşgörü, kadın yaptığında cezalandırma anlayışı Kur'an'da yoktur. Zina Yüce Allah'ın nazarında öylesine büyük bir günahtır ki, "Onlar, Allah ile beraber başka bir ilâha kulluk etmeyen, haksız yere, Allah'ın haram kıldığı cana kıymayan ve zina etmeyen kimselerdir. Kim bunları yaparsa ağır azaba uğrar." 99 ayetinde, büyük günahlar sıralamasında şirk ve adam öldürmenin hemen ardından getirilmiştir. ${ }^{100}$

Zina edenlere verilecek cezayı açıklayan ayette de kadın erkek ayrımı yapılmadan şöyle denir: "Zina eden kadın ve zina eden erkeğin her birine yüzer değnek (celde) vurun. Eğer Allah'a ve ahiret gününe iman ediyorsanız, onlara Allah'ın dini(ni uygulama) konusunda sizi bir acıma tutmasın; onlara uygulanan cezaya mü'minlerden bir grup da şahit bulunsun."101

Ayetin devamında bu fiziksel cezaya ek bir manevi ceza olsun diye, zina eden bir erkeğin ancak kendisi gibi zina etmiş veya müşrike olan bir bayanla evlenebileceği; zina eden bir kadının da kendisi gibi zina etmiş veya müşrik olan bir erkekle evlenebileceği, zinâkârlarla evlenmenin müminlere haram olduğu haber verilir. ${ }^{102}$ Dolayısıyla ne maddi cezalandırmada ve ne de manevi cezalandırmada kadınla erkek arasında bir ayrım yoktur.

8. Kadına Şiddete de Sebep Olan Zararlı Alışkanlıkları Yasaklaması: İnsanın hem dünyasını hem de ahiretini mahvedecek olan içki ve kumar, Kur'an tarafından yasaklanmıştır: "Ey iman edenler! (Aklı örten) içki (ve benzeri şeyler), kumar, dikili taşlar ve fal okları ancak, şeytan işi birer pisliktir. Onlardan kaçının ki kurtuluşa eresiniz."103

Hz. Peygamber, "Sarhoşluk veren her içki haramdır"104 demekle, ayette sadece hamr/şarap kelimesi zikredildi diye diğer sarhoşluk veren içkilerin haram olmadığı vehmini ortadan kaldırmıştır. Yine Kur'an'daki "Ey iman edenler! Siz sarhoş iken ne söylediğinizi bilinceye kadar... namaza yaklaşmayın" 105 ayeti yanlış yorumlanıp da bunların az miktarda içilmesinin

\footnotetext{
99 el-Furkân, 25/68.

${ }^{100}$ Râzî, Mefâtihu'l-gayb, 23/302.

101 en-Nûr, 24/2.

102 en-Nûr, 24/3.

103 el-Maide, 5/90.

104 Buharî, Eşribe, 4; Müslim, Eşribe, 67-68.

105 en-Nisâ, 4/43.
} 
helal olduğu sanılmasın diye "Çoğu sarhoş edenin azı da haramdır"106 buyurmuştur.

Kur'an'ın indiği dönemde bulunmayan uyuşturucu maddeler ise aralarındaki illet ${ }^{107}$ ortaklığı nedeniyle içkiyle aynı hükme tabidir ve haramdır. İçki, aklı perdelediği, kişiyi ne dediğini bilmez hale getirdiği, doğru ile yanlışı, hak ile batılı ayırt etmesini engellediği için haram kılınmıştır. Tüm bu saydığımız özellikler, esrar, eroin, kokain, morfin, bonzai, ecstacy vb. her gün yeni çeşitleri üretilen uyuşturucu maddelerde de fazlasıyla vardır. ${ }^{108}$

Bahsi geçen bu eylemlerin zararı sadece onu yapanlarla sınırlı kalmayıp, onların ailelerini de etkilemektedir. Bu tür eylemleri yapanların aile fertlerine karşı görevlerini olması gerektiği gibi yerine getirememesi ailede huzursuzluklara ve şiddet eylemlerine neden olmakta, pek çok yuvanın yıkılmasında rol oynamaktadır. Kur'an da onları açık bir şekilde yasaklayarak oluşabilecek mağduriyetleri ortadan kaldırmayı hedefler.

Kadının Dövülmesi Meselesi: Konu kadına yönelik şiddet olunca, Kur'an'daki "(Evlilik yükümlülüklerini reddederek) başkaldırdıklarını gördüğünüz kadınlara öğüt verin, onları yataklarında yalnız bırakın. (Bunlar fayda vermez de mecbur kalırsanız) onları (hafifçe) dövün. Eğer itaat ederlerse, artık onların aleyhine başka bir yol aramayın."109 ayetini ele almak, bir zorunluluktur. Öncelikle ayetin sebeb-i nüzulüne göz atmak, ayetin doğru anlaşılmasına katkı sağlayacaktır.

Ayet, kocası tarafından kendisine tokat atılan ve durumu $\mathrm{Hz}$. Peygamber'e şikâyete gelen Muhammed b. Seleme'nin kızı ile onun kocası Sa'd b. er-Rebî' hakkında inmiştir. Sa'd, hanımına bir tokat atmış, hanımı, tokadın izi hâlâ yüzündeyken Hz. Peygamber'e gelerek kocasını şikâyet etmiştir. Hz. Peygamber, kadına 'Kocandan öcünü al (sen de ona vur)' deyince “Gerçek hükümdar olan Allah, yücedir. Sana O'nun vahyi tamamlanmazdan

\footnotetext{
${ }^{106}$ Ebu Dâvud, Eşribe, 5; Tirmizî, Eşribe, 3.

107 İllet, "hükmü gösteren veya gerekli kılan yahut hükmün kendisine bağlandığı durum, vasıf, mana, gerekçe" şeklinde tarif edilir. Yani Şarii'in hükmü kendisine dayandırdığı; varlığı hükmün varlığı, yokluğu da hükmün yokluğu anlamına gelen temel gerekçedir. Bkz. Türkiye Diyanet Vakfı İslam Ansiklopedisi, İbrahim Kâfi Dönmez, (İstanbul: TDV Yay., 2000), "İllet" maddesi.

${ }^{108}$ Komisyon, et-Tefsîru'l-vasît li'l-Kur'âni'l-Kerîm, (Kahire: el-Hey'etu'l-âmmetu li-şuûnil-metâbi'i'lemîriyyeti, 1973), 1/354.

109 İhtilaflara meydan vermemek adına ayetin anlamı Diyanet İşleri Başkanlığının mealinden alınmıştır. Bkz. Halil Altuntaş, Muzaffer Şahin, Kur'an-ı Kerim Meali, (Ankara: DỉB Yayınları, trs), 93.
} 
önce Kur'an'ı (okumakta) acele etme ve 'Rabbim, benim ilmimi artır' de"110 ayeti inmiş; Hz. Peygamber, karar verirken acele etmemesi için uyarılmıştır. ${ }^{111}$ Bunun üzerine Hz. Peygamber, Yüce Allah'ın bu konuda bir ayet indireceği umuduyla kadına sabretmesini tavsiye etmiş, derken bu ayet inmiştir. ${ }^{112}$

Ayetteki ‘dövün' kelimesinin nasıl anlaşıldığına gelince; bunun, yorumcunun içinde yaşadığı toplum ve dönemle ilgili olduğunu rahatlıkla söyleyebiliriz. İslam'ın ilk zamanlarından, insan hakları ve kadın hakları gibi kavramların ciddi anlamda gündeme alındığı, üzerine hararetli tartışmaların yapıldığı 19. yüzyılın sonlarına kadar ayetteki kelime, gerçek anlamda dövme olarak algılanmıştır. Mücâhid (ö. 104), ${ }^{113}$ Taberî (ö. 310), ${ }^{114}$ Râzî (ö. 606), ${ }^{115}$ Suyûtî (ö. 911), ${ }^{116}$ Kâsımî (ö. 1332) ${ }^{117}$ gibi isimlerin yorumlarına baktığımızda, hepsinin 'kavvâm' kelimesini, 'güçlü olma, peygamberlerin erkeklerden olması, ezan okuma, nikâhta ve talakta yetkili olma, malından yaptığı harcama, evin ihtiyaçlarını karşılama, aile fertlerini görüp gözetme, terbiye etme, gerektiğinde vatan için savaşma, mirastan iki kat pay alma, had uygulanan suçlarda şahitlik edebilme, imamlık yapabilme (gerek devlet başkanlığı gerekse de bildiğimiz imamlık), hutbe verme, mehir verme gibi çeşitli nedenlerle erkeğin kadından üstün yaratılması olarak anladıklarını ve kadının yuvanın yıkılmasına neden olacak tavırlar sergilemesi durumunda, bir hukuk tedbiri olarak, hem kadının hem de ailenin maslahatını temin etme adına erkeğin onu dövebileceğini söylediklerini görürüz. Yani keyfi değil, yuvanın yıkılmasını önlemeye yönelik dövmeyi caiz görürler.

Ancak son dönem yorumcularına baktığımızda; kimi, Kur'an'ın indiği dönemde dövmenin çok yaygın olduğunu ve Kur'an'ın bunu ilkin azaltmaya ve sonra da tamamen kaldırmaya çalıştığını söyleyerek dövmenin varlığını kabul ederken;118 kimi, bu ayetin Kur'an bütünlüğü içinde ele alınması gerektiğini, Kur'an'ın 'Dövme hakkı' diye bir hak vermediğini, müsaade edilenin kadının

\footnotetext{
110 Tâhâ, 20/114.

${ }^{111}$ Celaluddin es-Suyûtî, ed-Durru'l-mensûr, (Beyrut: Dâru'l-fikr, ts), 2/513.

112 Muhammed b. Cerîr et-Taberî, Câmiu'l-beyân fî te'vîli'l-Kur'an, nşr. Ahmed Muhammed Şakir, (Beyrut: Müessesetu'r-risâle, 2000), 8/291; Ebu Bekr Muhammed b. İbrahim b. el-Munzir, Kitâbu tefsîri'l-Kur'ân, nşr. Sa'd b. Muhammed es-Sa'd, (Medine: Dâru'l-meâsire, 2002), 2/685; Râzî, Mefâtihu'l-gayb, 10/70; İbnu'l-Cevzî, Zâdu'l-mesîr, 1/401.

${ }^{113}$ Ebu'l-Haccâc Mücâhid b. Cebr, Tefsîru Mücâhid, nşr. Muhammed Abdusselâm, (Mısır: Dâru'lfikri'l-İslâmi'l-hadîse, 1989), 274.

114 Taberî, Câmiu'l-beyân, 8/290.

115 Râzî, Mefâtihu'l-gayb, 10/70-78.

116 Suyûtî, ed-Durru’l-mensûr, 2/512-513.

117 el-Kâsımî, Mehâsinu't-te'vîl, 3/97.

${ }^{118}$ Hayrettin Karaman, İslam'da Kadın ve Aile, (İstanbul: Ensar Yayınları, 1994), 25-187.
} 
saldırganlığı karşısında kendini savunmaktan ibaret olduğunu söyleyerek dövmeye karşı çıkar. ${ }^{119}$

Öztürk (ö. 2016) ise اضربوا fiilinin diğer anlamlarına ve bablarına bakılarak ona yeni bir anlam verilmesi gerektiğini savunur. Mesela kelimenin if'al babından 'evden çıkarma', 'bulundukları yerden gönderilme', 'dövme' anlamlarına gelebileceğini, seçimin karşılaşılan sorunun büyüklüğüne göre ayarlanması gerektiğini belirtir. İlk iki anlamın, sonuç alma, kadının psikolojisi ve hukuksal sorunlar yaşamama noktasında üçüncüye göre daha uygun olduğunu söyler. ${ }^{120}$

Mevdudî (ö. 1979), Hz. Peygamber'in dayağı yasakladığını, kadınlar tamamen kocalarını dinlemez hale gelince istemeden de olsa dayağa izin verdiğini ancak yine de kadın dövenlerin en hayırsız kişiler olduğuna vurgu yaptığını hatırlatır. ${ }^{121}$ M. Said Şimşek, İmam Şafii'nin (ö. 204) 'Dövmek, sadece ruhsat iken dövmemek daha büyük bir erdemdir' sözünü hatırlatarak $\mathrm{Hz}$. Peygamber'in ömrü boyunca hiçbir eşine ya da çocuğuna el kaldırmadığını söyler. ${ }^{122}$ İbn-i Aşûr (ö. 1973) ise, bir babanın evladını veya bir öğretmenin öğrencisini dövmesi miktarında olan tedip amaçlı dövmelerin kocanın hakkı olduğunu; kadının ciddi bir hayâsızlık yapması durumunda aile kurumunu kurtarmak için cezalandırılması gerekirse, bunun mahkeme kararıyla ve devlet eliyle olacağını söyler. ${ }^{123}$

Karslı, eski ve yeni yorumları verdikten sonra, yorumun içinde yaşanılan toplumdan nasıl etkilendiğini, sosyo-kültürel yapının ve toplumun bir parçası olan yorumcunun sosyo-psikolojik yapısının yaklaşım tarzına nasıl etki ettiğini analiz eder. İlk dönemle son dönem arasındaki farkın nedenlerini açıklamaya çalışır. ${ }^{124}$ Bir İslam hukukçusu olan Telkenaroğlu ise olaya hukuk zaviyesinden

\footnotetext{
${ }^{119}$ Hüseyin Hatemi bir müfessir değildir. Ancak onun yaptığı yorum, farklı bir bakış açısı ortaya koyduğu için burada kendisine yer verilmiştir. Bkz. Hüseyin Hatemi, İlahi Hikmet'te Kadın, (İstanbul: İşaret Yayınları, 1995), 143.

120 Yaşar Nuri Öztürk, Kur’an’daki İslam, (İstanbul: Yeni Boyut Yayınları, 1997), 554-555.

${ }^{121}$ Mevdûdî̀nin dayanağı "Hz. Peygamber, 'Allah'ın kızlarını (kadınları) dövmeyiniz' dedi. Derken Hz. Ömer geldi ve 'Ya Rasulellah! Kadınlar kocalarının tepesine çıktılar' dedi. Hz. Peygamber, onların dövülmesine ruhsat verdi. Bu defa da pek çok kadın $\mathrm{Hz}$. Peygamber'in ailesine gelerek kocalarını şikâyet ettiler. Hz. Peygamber, 'Muhammed ailesini kocasını şikâyet eden pek çok kadın ziyaret eder oldu. (Biliniz ki kadınlarını dövenler) sizin iyileriniz değillerdir' dedi” (İbn Mâce, Nikâh, 51) şeklindeki hadis-i şeriftir. Ebu'l-A'lâ Mevdûdî, Tefhîmu'l-Kur'an, (İstanbul: İnsan Yayınları, ts.), $1 / 357$.

${ }^{122}$ M. Said Şimşek, Hayat Kaynağı Kur’an Tefsiri, (İstanbul: Beyan Yayınları, 2012), 1/503.

${ }^{123}$ Muhammed et-Tâhir b. Âşûr, et-Tahrîr ve't-tenvîr, (Tunus: ed-Dâru't-tûnusiyye li'n-neşr, 1984), 5/41-43.

124 Ibrahim Halil Karslı, Kur'an Yorumlarında Kadın Sosyo-kültürel Çevrenin Kur’an Yorumlarındaki Yansımaları, (İstanbul: Rağbet Yayınları, 2003), 154-163.
} 
yaklaşarak dövmenin, nasihat verme ve yatağında yalnız bırakma tedbirlerinin işe yaramaması durumunda devreye giren, sınırları belirlenmiş hukukî bir müeyyide olduğunu savunur. Her hukukî müeyyide gibi tedip hakkının da suiistimale ve keyfiliğe yer verilmeyecek şekilde kullanılması gerektiğini söyler, uyulması gereken sınırları açıklar. ${ }^{125}$

Ayetin içine nazil olduğu sosyo-kültürel ortamda kadının insan yerine konulmadığı, çok rahatlıkla öldüresiye dövülebildiği bilinen bir durumdur. Buna dikkat çeken Hz. Peygamber, "Nereye kadar (böyle devam edecek), sizden biri, belki de günün sonunda aynı yatağı paylaşacağı eşini, köle (veya cariye) döver gibi dövüyor"126 demiştir. Kur'an, kadınları kastederek erkeklere hitaben, "Onlarla güzel geçinin"127 emri verir. Yine hem kadınları hem de çocukları cehennem ateşinden koruma görevini erkeklere yükleyen bir ayette, "Ey iman edenler! Kendinizi ve ailenizi, yakıtı insanlar ve taşlar olan ateşten koruyun"128 der. Bu ayete göre erkek, sadece kendisini değil, aynı zamanda aile fertlerini de cehennemden kurtarmakla görevlidir ve bunun için onlara gerekli eğitim ve öğretimi vermek, icabında onları tedip etmek zorundadır. Tabi insanların her zaman sorunsuz yaşadığı, tamamen uyumlu hareket ettikleri söylenemez. Eşler arasında sorunlar yaşanabildiği gibi, anne-baba ile çocuklar arasında da sorunlar yaşanabilmektedir. Kur'an, eşler arası problemleri çözmede altı basamaklı bir yol haritası önerir: 1- Onlara öğüt vermek, 2- Yatağını ayırmak, 3- Dövmek. Bu üç madde yukarıdaki ayete (en-Nisâ, 4/34) dayanmaktadır. 4Biri kadının diğeri erkeğin tarafından olmak üzere işi düzeltmeye yönelik hakemler belirlemek. Bu da önceki ayetin devamındaki ayete dayanır. ${ }^{129} 5$ - İki talaka kadar dönme imkânı olacak şekilde boşamak. Eşlerin birbirlerinin değerini anlamasını ve ayrı yaşamaya ne kadar hazır olduklarını test etmesini sağlama amacı güder. 6- Son kararı vermek ve ya bir daha dönüş imkânı olmayan tarzda üçüncü talakla boşamak ya da güzellikle eşine geri dönmek. Bu iki madde de "(Dönüş yapılabilecek) boşama iki defadır. Sonrası, ya iyilikle geçinmek, ya da güzellikle bırakmaktır"130 ayetine dayanır.

\footnotetext{
125 M. Rahmi Telkenaroğlu, İslam Hukukunda Ihmalî Suçlar, (Konya: Hüner Yayınları, 2014), 157159.

126 İbn Mâce, Nikâh, 51.

127 en-Nisâ, 4/19.

128 et-Tahrîm, 66/6.

129 "Eğer karı-kocanın arasının açılmasından endişe ederseniz, erkeğin ailesinden bir hakem, kadının ailesinden bir hakem gönderin. İi taraf (arayı) düzeltmek isterlerse, Allah da onları uzlaştırır. Şüphesiz Allah, hakkıyla bilendir, hakkıyla haberdardır." en-Nisâ, 4/35.

130 el-Bakara, 2/229.
} 
Görüldüğü gibi ilk ve tek çözümü kadını ölesiye dövmek olan bir topluma, altı aşamalı bir çözüm önerisi sunmuştur. Üstelik bu aşamaların bir bağlayıcılığı da yoktur. Hz. Peygamber, eşlerinin dünyevi talepleri karşısında bunaldığında onlara nasihatlerde bulunmuş, daha sonra onlardan ayrılarak 29 günlüğüne mescitte yalnız yaşamıştır. Bilahare dövmeye müracaat etmeden son bir kez kendileriyle konuşarak istedikleri dünya rahatını onlara sunamayacağını, bu yaşama razı oluyorlarsa birlikte devam edebileceklerini, kabul etmemeleri halinde kendilerini boşayarak babalarının evinde aradıkları rahatlığa kavuşmalarını sağlayacağını söylemiştir. Eşleri onunla yaşamayı seçince, evliliklerine devam etmişlerdir. ${ }^{131}$

Kur'an'daki emir fiilleri normalde vücûb ifade ederler. Ancak naklî ya da aklî bir delilin varlığı durumunda, vücûb ifade etmedikleri de olur. ${ }^{132}$ Mesela ihramdan çıkıldığında avlanabilmeye izin veren fiil, ayette "فَاصنُطَادُو - avlanın"133 şeklinde emir siygasıyla gelir. Bu, işinizi gücünüzü bırakıp ava çıkın anlamına gelmez. Sadece ihram yasağının sona erdiğini ve artık avlanmakta bir beis olmadığını gösterir ve ibâha ifade eder. Kadınlarla ilgili ‘dövün' emri de vücûb ifade etmez. Nitekim Hz. Peygamber'in yukarıda yer verdiğimiz uygulaması, yani naklî delil/sünnet, onun vücûb ifade etmediğini gösterir. Çünkü o (sav), dövmeden boşamayı teklif etmiştir.

Yine Kur'an tarafından bizim için en güzel örnek olduğu haber verilen $\mathrm{Hz}$. Peygamber'in 12 eş ve 7 çocuğundan hiçbirini dövmediği, hatta hizmetçisine bile el kaldırmadığı, ona hesap sormadığı bilinmektedir: "Enes b. Mâlik'ten şöyle rivayet edilmiştir: 'Rasulullah'a (sav) on yıl hizmet ettim. Bu zaman zarfında bana bir kez olsun 'öf' demedi. Yaptığım bir iş için, 'Onu niçin öyle yaptın?'; yapmadığım bir iş için de, 'Onu niçin yapmadın?' demedi.”134

Hz. Peygamber, "Bir mümin, mümine olan eşinden nefret etmesin. Bir huyundan hoşlanmazsa, bir diğerinden razı olur (hoşlanır)"135, "Kadınlara iyi davranın. Onlar sizin yardımcılarınızdır. Açık bir hayâsızlık yapmadıkları sürece onlar üzerinde zorbalık etmeyin. Eğer böyle bir şey yaparlarsa onları yataklarında yalnız bırakın ve onları incitici olmayan bir şekilde dövün. Eğer itaat ederlerse artık başka yol aramayın. Sizin onlar üzerinde hakkınız olduğu

\footnotetext{
131 Beğâvî, Meâlimu't-Tenzîl, 5/120.

132 Muhammed b. Ali et-Tayyib, el-Mutemed fî usûli'l-fıkh, nşr. Halil el-Meyyis, (Beyrut: Dâru'lkutubi'l-ilmiyye, 1403), 1/37-39.

133 el-Maide, $5 / 2$.

${ }^{134}$ Buharî, Edeb, 39; Müslim, Fedâil, 13; İbn Mâce, Nikâh, 51.

135 Müslim, Radâ, 61.
} 
gibi onların da sizin üzerinizde hakları vardır"136, "Müminlerin imanı en kâmil olanı, ahlakı en güzel olanıdır. Sizin en hayırınız da kadınlara karşı en hayırlı olandır"137, "Hayırlınız ailesine hayırlı olandır. Ailesine en hayırlı olanınız ise benim"138, "Allah'ım! İki zayıfın, yetim ve kadının hakkını yemekten sakındırırım"139 gibi sözleriyle her zaman kadınlara iyi davranmanın önemine dikkat çekmiş, erkeklerde bu yönde bir duyarlılık oluşturmaya gayret etmiştir.

Dolayısıyla Hz. Peygamber'in izinden gittiğini iddia eden her Müslüman, onu bu konuda da örnek almak; gücü yettiğince kadına sahip çıkmak; kadın sayesinde ahiretini kurtarmaya çalışmak zorundadır. Hadiste geçici dünyanın nimetleri içinde en üstünü olarak tarif edilen saliha bir eş, ${ }^{140}$ "Allah'ın rızasını gözeterek yaptığın her harcamadan, hatta eşinin ağzına koyduğun bir lokmadan dahi sana sevap vardır"141 hadisi gereği erkek için ömür boyu bir salih amel kaynağı, yani cennete gitme vesilesidir. Bu yüzden ona, hak ettiği şekilde güzel muamele etmek zorundadır.

\section{Sonuç}

Tarih boyunca insan eliyle oluşturulmuş pek çok hukuk nizamı, toplumda birlik ve beraberliği inşa etmeye; her hak sahibine hakkını eksiksiz bir şekilde vermeye; barış, huzur ve güveni tesis etmeye gayret etmiş, ancak aradaki ontolojik farklılık nedeniyle Kur'an'ın ulaştığı seviyeyi yakalayan bir nizam henüz çıkmamıştır. Her konuda ifrat ve tefritten uzak olan Kur'an, insan ve kadın hakları konusunda da en mutedil, en kabul edilebilir ve fitrata en uygun düzeni ortaya koymuştur.

Kadına yönelik şiddete neden olan her türlü olumsuzluğa karşı bir tedbiri olan Kur'an, onun maddi manevi her türlü hakkını teminat altına almıştır. Kadınlarla iyi geçinmeyi emretmiş, onların erkekler üzerindeki haklarına defaten vurgu yapmış, kadınları Allah adına emanet aldıklarını erkeklere hatırlatmıştır. Her türlü yaralama ve cinayeti kısas ilkesiyle minimize etmiş, erkekle kadın arasındaki fıtrat farkını göz önünde bulundurarak ekonomik hak ve yükümlülükleri adaletle dağıtmıştır. Kısas sayesinde öldürdüğü zaman

\footnotetext{
136 İbn Mâce, Nikâh, 3.

${ }^{137}$ Ebu Dâvud, Sünnet, 15.

138 İbn Mâce, Nikâh, 50.

139 İbn Mâce, Edeb, 6.

140 “Dünya geçici bir yararlanmadan ibarettir. Dünya nimetlerinin en üstünü de saliha kadındır.” İbn Mâce, Nikâh, 5.

${ }^{141}$ Buharî, İman, 41.
} 
öldürüleceğini, yaraladığı zaman aynı şekilde karşılık alacağını bilenlerin, buna tevessül etmelerinin önüne geçmiştir.

Doğum yapma, çocuk büyütme gibi yaratılış özellikleri gereği zamanının çoğunu evde geçirmek zorunda olan kadına, miras, mehir ve nafaka gibi mali haklar tanımıştır. Kur'an'ın öngördüğü nafaka, günümüz kanunlarında olduğu üzere ömür boyu devam ederek erkeğe zulmetmediği gibi Cahiliye Döneminde olduğu üzere hiçbir şey verilmeyerek kadına da zulmetmez. Bir evliliğin bitiminde, kadının yeni bir yuva kurmasına yetecek makul bir süre nafaka vermeyi erkeğe emreder. Ancak bu makul süre bittikten sonra kadın hâlâ bir yuva kuramamışsa, onun bakımını mirastan iki kat pay alan erkek kardeşlerine; onlar yoksa mirastan pay alan diğer asabeye yükler. Yani kadını, öncelikle birinci dereceden akrabaları üzerinden sigortalar. Tüm bunların bulunmaması durumunda kadının her türlü giderini karşılayacak olan, beytülmaldir. Yani sahipsiz bir kadının sahibi, devlettir, tüm toplumdur. Bunda da bir adalet vardır. Zira mirasçısı olmayan birinin ölümü durumunda onun malını alan beytülmal, kimsesiz kalan bir kadına da bakmak zorundadır.

Ancak günümüz kanunları ve örfi uygulamalar, kadını sadece eski kocasına yüklenmeye mecbur etmektedir. Babası öldüğünde erkek kardeşler, kadından miras hakkından vazgeçmesini talep etmekte ve onu örf baskısıyla mirastan mahrum bırakmaktadırlar. Bazen de baba, daha sağlığında var olan malını erkek çocukları arasında paylaştırmakta, kızlarını mirastan mahrum bırakmaktadır. Koca da evliliğin başında vermesi gereken mehri vermeyerek kadını mahrum etmektedir. Bilahare bir boşanma vaki olduğunda, yıllarca çalışıp didinmesine rağmen kadının elinde kalan, koca bir hiçtir. Erkek kardeşler kadına evlerinin kapısını da kapayınca, ne gidecek yeri ne de geçinecek malı olan kadın, kanunların verdiği imkânı sonuna kadar kullanmaya; erkekten alabildiği kadar mal almaya yönelmektedir.

Günümüz kanunlarında evlenme esnasında mal tespiti yapan bir sözleşme (mal rejimi sözleşmesi) imzalanarak tarafların sahip oldukları mallar belirlenmişse, bunlar boşanma sırasında paylaşıma dâhil edilmemektedir. Sadece evlilik süresince edinilen mallar, boşanan çiftler arasında eşit olarak paylaşılmaktadır. Ancak böyle bir mal rejimi sözleşmesi imzalanmamışsa, ev, araba, arsa, ev eşyası gibi tüm mallar, kazananın kim olduğuna bakılmaksızın kadınla erkek arasında ortaktır. Yargıtay'ın takı kararı gereği, düğünde takılan tüm takılar sadece kadına aittir. Boşanan erkek, ömür boyu kadına nafaka vermek zorunda olup; varsa çocukların velayeti çok istisna durumlar hariç 
kadına verilmektedir. Eğer erkek, kadına şiddet uygulamışsa ve kadın bunu ispatlarsa, bunun için de ayrıca tazminat ödemesi gerekmektedir. Tüm bunlar eşleri birbirine düşman etmekte, genellikle de erkek, haksızlığa uğradığını düşünerek şiddete başvurmaktadır. Erkeğin açısından bakıldığında, ömür boyu çalışıp kazandığı tüm malının yarısını, sadece 15 günde bir görmek üzere evlatlarını, düğünde takılan takıların \%75'i erkek tarafından geldiği halde takıların tamamını yitiren ve ömür boyu kadına maaş bağlamak zorunda bırakılan erkeğin haksızlığa uğradığını düşünmesi son derece doğaldır.

Kadın açısından baktığımızda; babası ve erkek kardeşleri, onu mirastan mahrum bırakmakla; babanın ölümünden sonra kendilerine sığındığı erkek kardeşleri, ona kapısını kapamakla; kocası, hakkı olan mehri vermemekle kadına zulmetmiş, onu çaresiz bırakmıştır. O da başka imkânı kalmadığı için yukarıda saydığımız şekilde eski kocaya rücu etmek zorundadır. Hâlbuki detaylarını verdiğimiz Kur'an tarafından konulan ilkeler uygulansa, tüm bunlara gerek kalmayacaktır. Mirastan hakkını, evliliğin başında mehrini alan kadın, kardeşleri ve/veya asabesi tarafından da diğer ihtiyaçları karşılandığı zaman, eski kocasına ihtiyaç duymayacağı için az önce bahsettiğimiz yollara başvurmayacaktır. Ya da tüm bu imkânlardan mahrumsa, kadına beytülmal/devlet sahip çıktığında yine eski kocayla maddi anlamda bir problemi olmayacaktır. Dolayısıyla erkeğin şiddete yönelmesi için bir sebep kalmayacak, boşanmış bile olsalar birbirlerine olan saygılarını kaybetmeyecek, çocuklarının iyi ve kötü günlerinde yanında olabileceklerdir.

Bu saydıklarımız, "Şiddetin Nedenleri” başlığında yer verdiğimiz pek çok nedeni ortadan kaldırmaktadır. Bir de içki, kumar, uyuşturucu gibi zararlı alışkanlıkların neden olduğu şiddet vardır ki Kur'an, tüm bunları net bir şekilde yasaklamıştır. Öyleyse toplumda yeniden huzuru hâkim kılmanın ve saadet asrına dönmenin yegâne yolu, Kur'an ve sünnet temelli bir toplum inşa etmektir. Cahiliye toplumundan Asr-ı Saadet toplumunu vücuda getiren Kur'an, aynı şeyi yapmaya her zaman için muktedirdir. Yapılacak tek şey, ona bu imkânı vermektir. Yapılacak diğer bir şey de yaşlı-genç bütün müminleri yeterli bir İslamî eğitim ile yetiştirerek, gerçek İslam'ı içselleştirmelerini ve bu yolla İslam dışı gelenekleri geriye itmelerini sağlamaktır.

\section{Kaynakça}


Akbulut, İlhan. "İslam Hukukunda Suçlar ve Cezalar”, AÜIFD, 52/I (2003): 167181.

Altuntaş, Halil, ve Muzaffer Şahin. Kur’an-ı Kerim Meali, Ankara: DỉB Yayınları, trs.

Âmedî, Ebu'l-Hasen Seyyiduddîn Ali b. Ebî Ali. Gâyetu'l-merâm fî ilmi'l-kelâm. nşr. Hasen Mahmûd Abdullatîf. Kahire: el-Meclisu'l-e'alâ li'ş-şuûni'lİslâmiyye, ts.

Beydâvî, Nâsıruddîn Ebû Saîd Abdullah b. Ömer. Envâru't-tenzîl ve esrâru'tte'vîl. nşr. Muhammed Abdurrahman el-Maraşlı. Beyrut: Dâru ihyâi'tturâsi'l-arabî, 1418.

Buhârî, Ebu Abdillah Muhammed b. İsmâil. el-Câmiu's-Sahîh. İstanbul: Akçağ Yayınları, 1988.

Çalışkan, İbrahim. “İslâm Hukukunda Ceza Kavramı ve Hadd Cezaları”, $A U ̈ I F D$, 31/l (1990): 367-397.

Çötok, Nesrin Akıncı. "Toplumsal Cinsiyet Rolü Dâhilinde Kadına Şiddet Olgusuna Karşı Kadın Algısı." International Journal of Social Sciences and Education Research, 1/III (2015): 778-790.

Demir, Sevim Atila, ve Dilek Nam. "Kadına Yönelik Aile İçi Şiddeti Önlemede Erkeğin Rolü." Süleyman Demirel Üniversitesi Iktisadi ve Idari Bilimler Fakültesi Dergisi, 19/III (2014): 211-227.

Ebu Dâvud, Süleyman b. el-Eş'as es-Sicistânî. Sünenu Ebî Dâvud. İstanbul: Akçağ Yayınları, 1988.

Ebu's-Suûd, Muhammed b. Muhammed. İşâdu'l-akli's-selîm ilâ mezâya'lkitâbi'l-kerîm. Beyrut: Dâru ihyâi't-turâsi'l-arabî, ts.

Erdoğan, Semra, Aylin Aktaş, ve Güliz Onat Bayram. "Sığınma Evinde Yaşayan Bir Grup Kadının Şiddet Deneyimleri Ve Baş Etme Yaklaşımları: Niteliksel Bir Çalışma." Uluslararası Insan Bilimleri Dergisi, 6/l (2009): 808-824.

Ermî, Muhammed el-Emîn b. Abdillah. Tefsîru hadâiku'r-ravhi ve'r-reyhân. Beyrut: Dâru tavki'n-necât, 2001.

Hatemi, Hüseyin. Ilahi Hikmet’te Kadın. İstanbul: İşaret Yayınları, 1995.

Hâzin, Alâuddîn Ali b. Muhammed. Lubâbu't-te'vîl fî meâni't-tenzîl. Beyrut: Dâru'l-kutubi'l-ilmiyye, 1415. 
Gökkaya, Veda Bilican. "Cam Tavan, Kadın ve Ekonomik Şiddet.” The Journal of Academic Social Science Studies, 26/II (2014): 371-383.

Güler, Nuran, Hatice Tel, ve Fatma Özkan Tuncay. "Kadının Aile İçi Şiddete Bakışı." CÜ Tıp Fakültesi Dergisi, 27/II (2005): 51-56.

http:/gazetekarinca.com/2017/12 /yuzune-kezzap-atilan-kadin-devlet-10-gunonce-koruma-talebimi-reddetmisti/ (erişim 02 Mayıs, 2018)

http://kadininstatusu.aile.gov.tr/data/58528516369dc524d057a5fe/Kad\%C4\%

B1na\%20Yo\%CC\%88nelik\%20\%C5\%9Eiddetle\%20Mu\%CC\%88cadel e\%20Bro\%C5\%9F\%C3\%BCr\%C3\%BC.pdf (erişim 01 Mayıs, 2018)

http://www.ceza-bb.adalet.gov.tr/mevzuat/5275.htm (erişim 10 Mayıs, 2018)

http://www.islamveihsan.com/mehir-nedir-mehir-neden-verilir.html (erişim 01 Haziran, 2018)

https://www.youtube.com/watch?v=J2jbYk7Srys (erişim 11 Mayıs, 2018)

İbn Âşûr, Muhammed et-Tâhir. et-Tahrîr ve't-tenvîr. Tunus: ed-Dâru't-tûnusiyye li'n-neşr, 1984.

İbn Atiyye, Ebu Muhammed Abdulhakk el-Endelûsî. el-Muharreru'l-vecîz fî tefsîri'l-kitâbi'l-azîz. nşr. Abdusselâm Abduşşâfî Muhammed. Beyrut: Dâru'l-kutubi'l-ilmiyye, 1422.

İbn Ebî Şeybe, Ebu Bekr. el-Kitâbu'l-musannef fi'l-ehâdisi ve'l-âsâr. Riyad: Mektebetu'r-ruşd, 1409.

İbn Mâce, Muhammed b. Yezîd. Sünenu İbni Mâce. İstanbul: Akçağ Yayınları, 1988.

İbn Munzir, Ebu Bekr Muhammed. Kitâbu tefsîri'l-Kur'ân. nşr. Sa'd b. Muhammed es-Sa'd. Medine: Dâru'l-meâsire, 2002.

İbnu'l-Cevzî, Cemâluddîn Ebu'l-Ferec Abdurrahman b. Alî b. Muhammed. Zâdu'l-mesîr fî ilmi't-tefsîr. nşr. Abdurrezzak el-Mehdî. Beyrut: Dâru'lkutubi'l-arabî, 1422.

İbnu'l-Humâm, Kemâluddîn Muhammed b. Abdilvâhid. Şerhu fethi'l-kadîr. Beyrut: Dâru'l-kutubi'l-ilmiyye, 1998.

Kadâî, Ebû Abdillah Muhammed b. Ca'fer. Müsnedu'ş-şihâb. Beyrut: Müessesetu'r-risâle, 1986.

Kahraman, Selam Dinç. "Kadınların Toplumsal Cinsiyet Eşitsizliğine Yönelik Görüşlerinin Belirlenmesi." DEUHYO ED, 3/l (2010): 30-35.

Karaman, Hayrettin. İslam'da Kadın ve Aile. İstanbul: Ensar Yayınları, 1994. 
Karaman, Hayrettin, Mustafa Çağırıcı, İ. Kâfi Dönmez, ve Sadrettin Gümüş. Kur'an Yolu. Ankara: DỉB Yayınları, 2014.

Karslı, İbrahim Halil. Kur'an Yorumlarında Kadın Sosyo-kültürel Çevrenin Kur'an Yorumlarındaki Yansımaları. İstanbul: Rağbet Yayınları, 2003.

Kâsımî, Muhammed Cemâluddîn. Mehâsinu't-te'vîl. nşr. Muhammed Bâsil Uyûnu's-Sevd. Beyrut: Dâru'l-kutubi'l-ilmiyye, 1418.

Kaypak, Şafak. "Türkiye'de Kadının İnsan Hakları Ve Anayasal Yansıması”, Mustafa Kemal Üniversitesi Sosyal Bilimler Enstitüsü Dergisi, 13/XXXIII (2016): 298-315.

Komisyon. et-Tefsîru'l-vasît li'l-Kur'âni'l-Kerîm. Kahire: el-Hey'etu'l-âmmetu lişuûnil-metâbi'i'l-emîriyyeti, 1973.

Mahallî, Celâluddîn Muhammed b. Ahmed, ve Suyûtî, Celâluddîn Abdurrahman b. Ebî Bekr. Tefsîru'l-Celâleyn. Kahire: Dâru'l-hadîs, ts.

Mandaloğlu, Mehmet. "İslamiyet'ten Önce Türklerde Aile Hukuku”, Türkiyat Araştırmaları Dergisi, 33 (2013): 133-159.

Mekkî b. Ebî Tâlib, Ebu Muhammed. el-Hidâyetu ilâ bulûği'n-nihâye. eş-Şârika: Mecmûatu buhûsi'l-kitâbi ve's-sünne, 2008.

Merâğî, Ahmed b. Mustafa. Tefsîru'l-Merâğî. Kahire: Şeriketu mektebetu ve matbaatu Mustafa el-Bâbî, 1946.

Mevdûdî, Ebu'l-A'lâ. Tefhîmu’l-Kur'an. İstanbul: İnsan Yayınları, ts.

MN Yazılım Medya Reklam A.Ş. "memurlar.net.” Erişim 03 Mayıs, 2018. https://www.memurlar.net/haber/439279/bosanmak-isteyen-esini-veesinin-ailesini-oldurdu.html

Muhammed b. Muhammed. el-Inâye şerhu'l-hidâye, Beyrut: Dâru'l-Fikr, trs.

Muhammed Reşid b. Ali Rıza. Tefsîru'l-menâr. Kahire: el-Hey'etu'l-mısriyyetu'lâmmetu li'l-kitâb, 1990.

Mücâhid b. Cebr, Ebu'l-Haccâc. Tefsîru Mücâhid. nşr. Muhammed Abdusselâm. Mısır: Dâru'l-fikri'l-İslâmi'l-hadîse, 1989.

Müslim b. el-Haccâc. Sahihu Müslim, İstanbul: Akçağ Yayınları, 1988.

NTV Radyo ve Televizyon Yayıncılığı A.Ş. "Televizyon (NTV)." Erişim 02 Mayıs, 2018. https://www.ntv.com.tr/turkiye/evlenme-teklifini-reddettidiye-olduruldu,Ep8eNYsRf0egtU72awVj_g 
Özcan, Uğur, ve Murat Gökhan Dalyan. "19. yy'da Rumlarda ve Arnavutlarda Evlilik Müessesesinde Başlık Uygulamaları", History Studies, 3/III (2011): 319-336.

Öztürk, Necla. "Ailenin Korunması Ve Kadına Karşı Şiddetin Önlenmesine Dair Kanunun Getirdiği Bazı Yenilikler ve Öneriler”, Inönü Üniversitesi Hukuk Fakültesi Dergisi, 8/l (2017): 1-32.

Öztürk, Yaşar Nuri. Kur'an'daki İslam. İstanbul: Yeni Boyut Yayınları, 1997.

Râzî, Ebu Abdillah Muhammed b. Ömer Fahruddîn. Mefâtihu'l-gayb. Beyrut: Dâru ihyâi't-turâsi'l-arabî, 1420.

Seâlibî, Ebu Zeyd Abdurrahman b. Muhammed. el-Cevâhiru'l-hisân fî tefsîri'lKur'ân, Beyrut: Dâru ihyâi't-turâsi'l-arabî, 1418.

Semerkandî, Nasr b. Muhammed b. Ahmed. Bahru'l-ulûm. Beyrut: Dâru'lkutubi'l-ilmiyye, 2010.

Suğdî, Ebu'l-Hasen Alî b. el-Huseyn. en-Nutefu fi'l-fetâvâ. nşr. Salahuddîn enNâhî. Beyrut: Dâru'l-Furkân, 1984.

Suyûtî, Celaluddin. ed-Durru'l-mensûr. Beyrut: Dâru'l-fikr, ts.

Şimşek, M. Said. Hayat Kaynağı Kur’an Tefsiri. İstanbul: Beyan Yayınları, 2012.

Taberî, Muhammed b. Cerîr. Câmiu'l-beyân fî te'vîli'l-Kur'an. nşr. Ahmed Muhammed Şakir. Beyrut: Müessesetu'r-risâle, 2000.

Tayyib, Muhammed b. Ali. el-Mutemed fî usûli'l-fıkh. nşr. Halil el-Meyyis. Beyrut: Dâru'l-kutubi'l-ilmiyye, 1403.

Telkenaroğlu, M. Rahmi. İslam Hukukunda Ihmalî Suçlar. Konya: Hüner Yayınları, 2014.

Tirmizî, Muhammed b. İsâ. Sünenu Tirmizî. İstanbul: Akçağ Yayınları, 1988.

Türer, Celal. Şiddet Karşısında İslam. İstanbul: DİB Yayınları, 2014.

Türkiye Diyanet Vakfı İslam Ansiklopedisi. Fahrettin Atar. 44 cilt. İstanbul, TDV Yay., 2006.

Türkiye Diyanet Vakfı İslam Ansiklopedisi. İbrahim Kâfi Dönmez. 44 cilt. İstanbul, TDV Yay., 2000.

Türkiye Radyo ve Televizyon Kurumu Haber ve Spor Yayınları Dairesi Başkanlığı. " "TRT HABER.” Erişim 06 Mayıs, 2018. http://www.trthaber.com/haber/gundem/egitimli-kadin-daha-cok-siddetgoruyur-20568.html 
Yazır, M. Hamdi. Hak Dini Kur’an Dili. İstanbul: Eser Neşriyat, 1979.

Yenigün Haber Ajansı Basın ve Yayıncılık A.Ş. "Cumhuriyet Gazetesi.” Erişim 01 Haziran, 2018. http://www.cumhuriyet.com.tr/haber/turkiye/ 443684/Aydin_da_koca_dehseti_Bosanmak_isteyen_esini_ve_iki_coc ugunu_katletti.html.

Zemahşerî, Ebu'l-Kâsım Muhammed b. Amr b. Ahmed. el-Keşşâf an hakâiki ğavâmidi't-tenzîl. Beyrut: Dâru'l-kitâbi'l-arabî, 1407. 


\title{
Violence Against Women: Causes And Qur'anic Measures For Prevention
}

Citation / @- Kılıçarslan, M. (2018). Violence Against Women: Causes and Qur'anic Measures for Prevention, Cukurova University Journal of Faculty of Divinity 18 (2), 958-994.

\begin{abstract}
Violence against women has become an untreatable wound of the world. Despite many official and unofficial studies, seminars, panels, symposiums, conferences, and even public works such as in-house family member trainings and a lot of new laws made to prevent violence against women; this unacceptable primitive behavior is unfortunately continuing to increase. Violence against women is a phenomenon that has many causes, especially women's weakness against men, women's gender / sexuality, rejection, economic reasons, cultural reasons, inadequacy of laws and human causes and it is a common problem with which the whole world struggles. However, some anti-Islamic formations continue to attack Islam through human rights and women's rights and they try to create negative views about Islam in that Islam is the unique reason behind domestic violence and violence is imposed on women only in Muslim countries. When the two sources of this religion, the Qur'an and the Sunnah, are examined, it will be seen that while the ancestors of those who are attacking Islam today were discussing whether or not the woman is a human being, Islam gave the woman all kinds of rights and powers. In this study, the causes of violence against women will be identified in titles, and then the Qur'anic measures to prevent violence against women are going to be focused. This study aims to help the readers who are provided to see the causes of violence against women collectively understand that this problem has nothing with Islam; and to help them realize that Quran is not a source of trouble, but a solution for this problem by highlighting them the Qur'an's measures to protect women.
\end{abstract}

Keywords- Women, violence, cause, Qur'an, measurement. 